\title{
Electrospun Nanofibre Composite Polymer Electrolyte Fuel Cell and Electrolysis Membranes
}

\author{
Rakhi Sood, Sara Cavaliere*, Deborah J. Jones, Jacques Rozière
}

Institut Charles Gerhardt Montpellier, UMR CNRS 5253, Agrégats Interfaces et Matériaux pour l’Energie, Université de Montpellier - 34095 Montpellier Cedex 5, France.

* Corresponding author: Fax: +33 (0)4 $67 \quad 1433$ 04; Tel: +33 (0)4 $67 \quad 1490$ 98; E-mail: sara.cavaliere@umontpellier.fr

\begin{abstract}
Large-scale commercialisation of Proton Exchange Membrane Fuel Cell (PEMFC) technology for automotive and stationary applications demands the development of a robust, durable and cost-effective materials. In this regard, ionomer membranes being present at the core of PEMFCs are required to maintain elevated proton conductivity, high mechanical strength and low gas permeability during the lifespan of the fuel cell. These challenges are addressed by investigating novel nano-structured membrane materials possessing long-range spatial organisation of ionic and hydrophobic domains at the micro- and nano-scales. Electrospinning, a versatile and easily up-scalable tool for the preparation of nanofibrous polymers and ceramics with targeted architectures, is being extensively applied for the development of nanostructured electrolyte membranes. This review describes the most important advances in the use of electrospun materials for the preparation of new generation fuel cell proton conducting membranes. It also highlights the challenges to be overcome and the new directions and future application fields of composite nanofibre-based membranes in the broader context of energy materials.
\end{abstract}


Keywords: PEMFC, DMFC, electrospinning, nanofibres, polymer electrolyte/proton conducting membranes, mechanical reinforcement, inorganic materials, crosslinking.

\section{Contents}

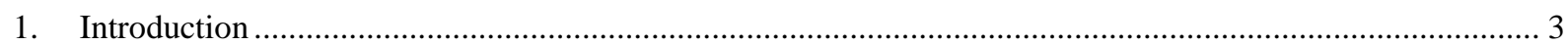

2. Composite membranes comprising an electrospun mat of uncharged nanofibres embedded in an ionomer matrix

3. Composite membranes comprising an uncharged polymer and an embedded 3D inter-connected mat of ionomer nanofibres

4. Composite membranes based on inorganic electrospun mats embedded in a polymer matrix. 16

5. Composite membranes of cross-linked electrospun mats embedded in a polymer matrix ................................ 20

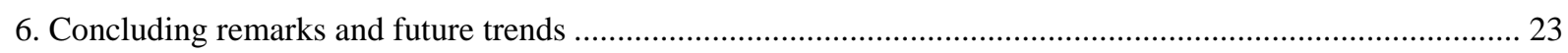

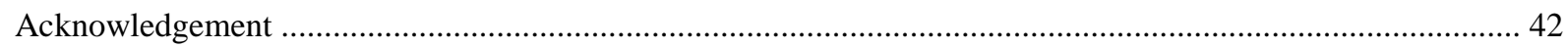

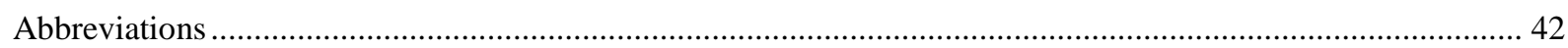




\section{Introduction}

Proton exchange membrane fuel cells (PEMFC) and water electrolysers (PEMWE) are expected to play significant roles in the near future in the electrification of transport, for heat and electricity supply in stationary applications, and as a means of large scale storage of renewable energy by using wind or solar energy to provide power for hydrogen generation by water electrolysis $[1,2]$. Despite their advanced development, costs must be further reduced, and the durability of the components over time must still be improved [3-5]. The Membrane Electrode Assembly (MEA) is the core component of these electrochemical energy conversion devices. The MEA comprises a proton exchange membrane, anode and cathode, as schematically represented in Figure 1. At the core of the MEA is the polymer membrane generally functionalised with either acid or basic groups [6-15]. The membrane separates the electrodes and prevents direct reaction of reactant gases and transport ions between the electrodes. It also provides mechanical integrity to the assembly. Proton conductivity in polymer electrolyte membranes strongly depends on water content as water molecules act as proton carriers [16]. Materials providing the best association of the above properties of conductivity, chemical stability and mechanical strength are perfluorosulfonic acid (PFSA) ionomers such as Nafion ${ }^{\circledR}$, Aquivion ${ }^{\circledR}, 3 \mathrm{M}$ Corporation ionomers. The high proton conductivity of PFSA-membranes is correlated with their morphology in which ionic domains are wellpercolated and phase-separated from hydrophobic domains that provide mechanical strength

[17]. The importance of the spatial organisation of hydrophilic and hydrophobic domains in determining the conductivity and mechanical properties of ionomer membranes is wellestablished $[18,19]$. This is influenced by the nature of the polymer backbone and side chain compositions, and the spatial organisation of functional and non-functional groups in random polymers and block copolymers. 
In an operating fuel cell or electrolyser, particular constraints or stresses arise that lead to accelerated materials ageing. For example, membrane mechanical failure is accelerated by the swelling and shrinkage that occurs during membrane hydration and dehydration that accompany operation under variable load [20]. Membranes showing little or no change in dimension at different water contents are required, since they will be more robust over time on fuel cell operation and extend MEA lifetime. They also allow the use of thinner membranes which facilitates water management in the cell, and lowers the electrical resistance. These factors have triggered extensive research on the development of improved proton exchange membranes comprising 1) Advanced perfluorosulfonic acid ionomers [21,22]; 2) PFSAionomer composite membranes [23,24]; 3) Functionalised polyaromatic or partiallyperfluorinated ionomers and their composite membranes [4,13,25-35], and4) Ionomers or polymers in combination with strong acids/heterocycles/ionic liquids [3,36-39]. Of all these approaches, novel sulfonated polyaromatic polymers, shorter side chain PFSAs, and composite membranes (polymer blends and inorganic-organic membranes) with PFSA or alternative sulfonated polymers have been greatly investigated.

Expanded PTFE (ePTFE) impregnated with Nafion ${ }^{\circledR}$ or other PFSA (e.g. Gore-Select ${ }^{\circledR}$ membrane) leads to reinforced membranes having excellent mechanical properties due to the presence of the ePTFE reinforcement, which allows the preparation of thin membranes (5-30 $\mu \mathrm{m})$ with low area resistance [40-42], but also low methanol crossover [43] that show much higher durability than non-reinforced membranes. Nevertheless, ePTFE reinforced membranes have lower proton conductivity than predicted from the inert polymer volume fraction, which has been attributed to the incompatibility between the highly ionic PFSA and the low-dielectric PTFE, resulting in an ionomer deficient layer [44]. Similarly, inorganic-organic membranes have markedly improved mechanical properties, resulting from the specific interactions between inorganic and organic components and the internal scaffolding role played by the 
inorganic material, that have enabled fuel cell operation at higher temperatures and lower relative humidity $(\mathrm{RH})$ in many cases in comparison to the corresponding non-modified membranes [45-50].

Electrospinning is increasingly recognised as a powerful means of introducing unique phaseseparated architectures into composite proton exchange membranes [51-55]. The electrospinning process leads to mechanically robust fibrous structures with diameters in the nano to micrometre range by utilising the electrical force between a drop of fluid polymer on a capillary tip and a grounded collector. As the intensity of the electric field increases, the hemispherical surface of the drop elongates to form a conical shape known as the Taylor cone. For a critical value of the applied electric field, the repulsive forces overcome the surface tension of the drop and a jet of the solution is ejected from the tip of the Taylor cone. The solvent evaporates during flight of the jet to the collector, and a mat of solidified continuous, ultra-thin fibres is formed. Figure 2 is a schematic illustration of an electrospinning set-up and the Taylor cone jets issued from the electrified nozzle during the electrospinning process. The electrospinning technique is of particular interest in the development of fuel cell and electrolyser membranes since it allows introduction of a nanophase-separated morphology in composite systems [56]. Indeed, it allows the elaboration of composite membranes with a rather facile means to control of the long-range organisation/distribution/percolation of hydrophilic and hydrophobic domains of the ionomer by adjusting the type of electrospun material, the volume fraction of the nanofibres and the experimental conditions. Additionally, electrospinning can provide uniaxial alignment of the polymer chains within nanofibres, which can result in enhanced mechanical properties [57,58] and can promote the formation of interconnected channels which facilitate improvement in proton conductivity $[59,60]$.

All these factors have greatly increased the range of materials that can be prepared through electrospinning and explains the increased interest in the last decade. Figure 4 shows the 
number of articles published from 2005 to 2015 on electrospun materials for fuel cells (Figure 3 (a)) and electrospun polymer membranes for fuel cells in particular (Figure 3 (b)). Additionally, other recent articles have dealt with the general aspects and the trends in the development of materials for electrochemical energy storage and conversion devices using electrospinning [53-55,61,62]. This review focusses on the strategies employed for the development of polymer membranes incorporating an electrospun nanofibre component, and the interest as discussed in the recent literature for their application in fuel cells or electrolysers. The review is broadly organised according to four types of membrane architecture as presented in Figure 4: (a) electrospun mat of inert reinforcing nanofibres embedded in a proton conducting polymer, (b) electrospun mat of nanofibres of a proton conducting polymer embedded in an inert polymer, (c) an inorganic electrospun (proton conducting or non-conducting) nanofibre mat embedded into a (proton conducting or non-conducting) polymer matrix, (d) a cross-linked electrospun polymer mat embedded in a (proton conducting or non-conducting) polymer matrix.

\section{Composite membranes comprising an electrospun mat of uncharged nanofibres embedded in an ionomer matrix}

This strategy involves electrospinning a robust non-conducting or a weakly proton conducting material into a nanofibre mat, which acts primarily as a mechanical support, followed by its subsequent embedding (by impregnation, casting etc.) into a proton conducting polymer. Recent developments in the electrospinning technique have enabled the possibility to control spatial orientation of the electrospun fibres and hence well-aligned and highly ordered architectures can be elaborated, which can further increase the reinforcing effect of the electrospun mat in the composite membrane. An overview of membranes incorporating inert 
electrospun nanofibres is shown in Table 1. Typical polymers that have been used to produce electrospun reinforcements include polyvinylidene fluoride (PVDF), polyvinyl alcohol (PVA), polystyrene (PS), polysulfone (PSU and polyimide (PI) [63-75].

Several endeavours have been undertaken specifically to develop fuel cell membranes with reduced methanol crossover for direct methanol fuel cells (DMFC) by introduction of inorganic particles or inert polymers into the ionomer to act as a physical barrier and increase tortuosity [6]. For instance, PVDF, selected for its high resistance to methanol crossover, thermal stability and mechanical strength, has been combined with Nafion ${ }^{\circledR}$ to obtain blend membranes [76-78]. However, the resulting blend membranes were observed to suffer from insufficient mechanical strength, which was considered to be due to the partial miscibility between the two polymers, $[79,80]$ and from high cell resistance, which was attributed to poor compatibility of the membrane and the electrodes. In an attempt to overcome these drawbacks, Choi et al. developed membranes from electrospun PVDF and Nafion ${ }^{\circledR}$. The electrospun PVDF mats exhibited high porosity and formed a 3D inter-connected network that was intact within the composite membrane after impregnation with Nafion ${ }^{\circledR}$ [64], Figure 5 (a). The membranes presented lower proton conductivity than pristine Nafion ${ }^{\circledR}$. However, MEAs with the nanofibre composite membrane were reported to show better electrochemical performance than when using Nafion ${ }^{\circledR}$ 115 at $65^{\circ} \mathrm{C}$ in $2 \mathrm{M}$ methanol (Figure 5 (b)) which was attributed to improved interfacial contact with the electrodes as well as lower thickness of the composite membranes. In an attempt to enhance the compatibility at the interface between PVDF nanofibres and PFSA ionomer, Li et al. functionalised PVDF nanofibres with Nafion ${ }^{\circledR}[68,70]$. After impregnation of a Nafion ${ }^{\circledR}$ functionalised PVDF electrospun mat with Nafion ${ }^{\circledR}$, the resulting membrane was reported to present superior mechanical strength (Young's modulus of $1840 \mathrm{MPa}$ ) and methanol-barrier properties (methanol permeability of $0.86 \times 10^{-6} \mathrm{~cm}^{2} / \mathrm{s}$ ) compared to recast Nafion ${ }^{\circledR}$ with large thickness (Young's modulus of $1280 \mathrm{MPa}$ and methanol permeability of $1.46 \times 10^{-6} \mathrm{~cm}^{2} / \mathrm{s}$ ). 
Furthermore, its proton conductivity was observed to be higher $\left(60 \mathrm{mS} / \mathrm{cm}\right.$ at $\left.20{ }^{\circ} \mathrm{C}\right)$ than that of a Nafion ${ }^{\circledR}$ membrane comprising a mat of non-functionalised PVDF nanofibres, Nafion ${ }^{\circledR} 117$ or recast $\mathrm{Nafion}^{\circledR}(36,42,22 \mathrm{mS} / \mathrm{cm}$ respectively). The direct methanol fuel cell power density with $2 \mathrm{M}$ methanol for an MEA with the functionalised PVDF mat was $83 \mathrm{~mW} / \mathrm{cm}^{2}$ at $70{ }^{\circ} \mathrm{C}(60$ and $55 \mathrm{~mW} / \mathrm{cm}^{2}$ respectively in MEAs with Nafion ${ }^{\circledR} 117$ and recast Nafion with thickness of about $90 \mu \mathrm{m})$. The authors attributed the improved properties to the formation of proton conducting channels on the nanofibre surface [68]. The mechanical properties and proton conductivities of these membranes are shown in Figure 6 respectively.

The properties requirements for water electrolyser membranes are in many respects similar to those of fuel cell membranes however since the difference in pressure between anode and cathode sides in a water electrolyser can be several tens of atmospheres and the constraints in terms of membrane mechanical strength are even more stringent. Furthermore, the hydrogen permeability of an electrolyser membrane must be low enough to ensure that the safety threshold concentration of hydrogen in oxygen is not reached at the cathode through hydrogen crossover from the anode. The presence in the membrane of an electrospun nanofibre network of a robust polymer can help in satisfying both of these requirements. Polysulfone nanofibre reinforcements have been embedded in short-side-chain PFSA (Aquivion ${ }^{\circledR}$ ) membranes of ionomer equivalent weights $700-1000 \mathrm{~mol} / \mathrm{g}$. In each case, the Young's modulus of the reinforced membrane was greater than that of the corresponding non-reinforced membrane, and while the proton conductivity was lower, this was a consequence only of the lower ion exchange capacity of the membrane, and was not compounded by any other effect. The hydrogen crossover of the reinforced membranes was slightly lower than that of Nafion ${ }^{\circledR}$ [81]. Positive effects in particular on membrane mechanical properties are thus observed for composite membranes incorporating an electrospun nanofibre mat, even in the absence of specific interactions between the reinforcement and the proton conducting polymer. This is the case 
typically with PSU and PFSA for example; arguably hydrophobic interactions will operate in the case of PVDF reinforced PFSA. Nevertheless, stronger interactions between the reinforcing and matrix components, such as between a basic polymer and PFSA or sulfonic acid functionalised polyaromatic polymer, are expected to provide greater benefit. Further, in such acid-base systems a distinct induction effect is exhibited, by which protonation and deprotonation are promoted, resulting in superior low-energy-barrier proton hopping pathways [82].

In recent work, electrospun poly[2,2'-(m-phenylene)-5,5'-dibenzimidazole] (PBI) webs have been embedded into low $(700 \mathrm{~g} / \mathrm{mol})$ equivalent weight short-side-chain Aquivion ${ }^{\circledR}$. Furthermore, PBI fibres with very fine diameters $(120 \mathrm{~nm})$ were obtained by co-axial electrospinning with PBI in the core and an external solvent sheath. The effect of the PBI mat thickness on membrane conductivity and mechanical properties was investigated, and it was concluded that for thickness ratio of around 1 (PBI mat) to 3 (overall membrane thickness) the membrane mechanical properties showed significant improvement over those of non-reinforced EW $700 \mathrm{~g} / \mathrm{mol}$ Aquivion ${ }^{\circledR}$ (elastic modulus increased from ca. $40 \mathrm{MPa}$ to ca $160 \mathrm{MPa}$ ), while the membrane conductivity still exceeded $30 \mathrm{mS} / \mathrm{cm}$ at $110{ }^{\circ} \mathrm{C}, 50 \% \mathrm{RH}\left(160 \mathrm{mS} / \mathrm{cm}\right.$ at $80{ }^{\circ} \mathrm{C}$, $95 \%$ RH). PBI-reinforced Aquivion ${ }^{\circledR}$ membranes have shown exceptional stability and durability in fuel cell tests designed to accelerate chemical and mechanical degradation mechanisms, including open-circuit-voltage (OCV) hold testing at $85{ }^{\circ} \mathrm{C}$ and $13 \% \mathrm{RH}$, and wet-dry cycling at OCV (Figure 7) [83]. These results are attributed to ionic cross-linking with partial proton transfer from the ionomer to the basic sites of PBI nanofibres in the electrospun web, which improves the interface and the cohesion between the mat and the ionomer. Furthermore, heterocyclic polymers such as PBI are known to have antioxidant properties and thus the reinforcement may also provide chemical stabilisation by scavenging species such as peroxy free radicals that are produced during fuel cell operation and which attack the PFSA 
polymer in ways that are increasingly well understood. If this is borne out, this represents the first example of single additive to a membrane contributing to improvement of both mechanical and chemical stability.

In the studies discussed above, the electrospun nanofibre mats of inert polymers were combined with a PFSA ionomer. Lee et al. combined inorganic proton conducting sulfonic acid/phosphonic acid-functionalised silicate glass electrolytes synthesised from 3glycidyloxypropyl trimethoxysilane (GPTMS)/orthophosphoric acid $\left(\mathrm{H}_{3} \mathrm{PO}_{4}\right)$ or a GPTMS/ 3trihydroxysilyl-1-propanesulfonic acid (THPSA) mixture and an electrospun polyimide nonwoven, KFM-NT ${ }^{\circledR}[66,67]$. The flexibility of the composite membranes was improved over that of the silicate glass type membrane (Figure 8) [67], and the proton conductivity at $80{ }^{\circ} \mathrm{C}$ and $80 \% \mathrm{RH}$ of the GPTMS/THPSA $=1 / 9$ composite membrane $(166 \mathrm{mS} / \mathrm{cm})$ was higher than that of $\mathrm{Nafion}^{\circledR}(70 \mathrm{mS} / \mathrm{cm})$ or sulfonated polysulfone $(37 \mathrm{mS} / \mathrm{cm})$, which the authors attributed to the presence of a highly interconnected network of densely concentrated acid groups (IEC ca. $2.47 \mathrm{mmol} / \mathrm{g}$, sulfonated polysulfone: $1.56 \mathrm{mmol} / \mathrm{g}$; Nafion ${ }^{\circledR}: 1.03 \mathrm{mmol} / \mathrm{g}$ ) and large amount of chemically adsorbed water for the composite membrane.

Ballengee et al. have elaborated composite membranes by simultaneous electrospinning of charged $\left(\mathrm{Nafion}^{\circledR}\right)$ and inert components followed by post-electrospinning processing steps which result in different types of composite membrane architectures (ionomers fibres embedded into an inert matrix or vice versa) depending on the post-treatment (Figure 9) [84-86]. The details of this approach will be further addressed in the section 3 below. 


\section{Composite membranes comprising an uncharged polymer and an embedded 3D inter-connected mat of ionomer nanofibres}

This approach involves electrospinning an ion conducting material into a 3D interconnected network nanofibre mat that is impregnated typically with an inert component to obtain composite membranes. Here, the electrospun fibres provide the pathways for proton conduction while the inert component acts as the primary mechanical support of the system. Sanders et al. were the first to explore the possibility of utilising electrospraying and electrospinning to prepare proton conducting membranes incorporating Nafion ${ }^{\circledR}$ [87]. Since then, various research groups have investigated the elaboration of PFSA ionomer nanofibres using electrospinning. Table 2 presents the results of different investigations associated with the electrospinning of PFSA based polymers.

It is well-established that the electrospinnability of a polymer solution critically depends on entanglements of the polymer chains, which in turn depends on the molecular weight of the polymer as well as its concentration in the solution [88]. Perfluorosulfonic acid ionomers such as Nafion $^{\circledR}$, and short-side-chain (SSC) Aquivion ${ }^{\circledR}, 3 \mathrm{M}$ ionomers, etc., owing to the electrostatic interactions that result from their chemical structure comprised of a hydrophobic polymer backbone and side chains terminating in sulfonic acid groups, exhibit formation of aggregates or micelles in aqueous media and non-aqueous media [89]. This self-assembly behaviour of PFSA ionomers results in a low degree of chain entanglement and generally PFSA tends to electrospray as beads rather than electrospin into fibres. The addition of a high molecular weight carrier polymer and increase of the ionomer concentration in dispersion are means to overcome this situation.

Several carrier polymers such as PEO [90-92], PVA [90], PVP [93] and PAA [94] have been used to facilitate the electrospinning of PFSA ionomers. Nevertheless, PEO remains the one most commonly used due to its low quantities required to obtain uniformly-sized nanofibres of 
PFSA polymers, the importance of which will be discussed now. Laforgue et al. electrospun 5 wt\% Nafion ${ }^{\circledR}$ dispersion containing PEO $\left(\mathrm{M}_{\mathrm{w}}=200 \mathrm{kDa}\right)$ [90]. The resulting morphology of the deposited Nafion ${ }^{\circledR}$ changed from spheres, obtained using $4.8 \mathrm{wt} \%$ of PEO, to nanofibres with diameter between 80 and $180 \mathrm{~nm}$ when using $16.7 \mathrm{wt} \%$ PEO. The high content of PEO in the Nafion ${ }^{\circledR}$ nanofibres tended to lower the proton conductivity [91]. Pintauro et al. studied electrospinning of PFSA polymers with different side chain length and equivalent weight (Nafion ${ }^{\circledR}$ EW 1100 [95], Liquion ${ }^{\circledR} 1115$ [96], 3M EW 825 and 733 [91]) and investigated a range of experimental parameters, including air humidity, solvent, molecular weight of carrier polymer, applied voltage, polymer solution concentration and flow rate. These authors observed that bead-free nanofibres of 3M PFSA could be prepared using merely $1 \mathrm{wt} \%$ of PEO $\left(\mathrm{M}_{\mathrm{w}}=\right.$ $300 \mathrm{kDa}$ ) by using a higher total polymer concentration of $10 \mathrm{wt} \%$ rather than the $5 \mathrm{wt} \%$ used in previous works. Figure 10 presents SEM micrographs along with the diameter distribution histograms of electrospun mats prepared from $10 \mathrm{wt} \%$ solution containing different $\mathrm{wt} \%$ ratios of 3M PFSA (EW 825)/PEO [91]. Furthermore, an increase in the molecular weight of the carrier polymer from $300 \mathrm{kDa}$ to $1,000 \mathrm{kDa}$ enabled bead-free nanofibres with only $0.3 \mathrm{wt} \%$ PEO resulting in nanofibres with average diameter around $150 \mathrm{~nm}$. By use of very high molecular weight PEO $(8,000 \mathrm{kDa})$, Elabd et al. prepared Nafion ${ }^{\circledR}$ nanofibres with $400 \mathrm{~nm}$ average diameter with only $0.1 \mathrm{wt} \%$ PEO [97]. Dynamic light scattering provided evidence for interactions between the Nafion ${ }^{\circledR}$ and high $\mathrm{M}_{\mathrm{w}}$ PEO. All these examples showed that an increase in the solution viscosity facilitates the deposition of PFSA nanofibres using a very low weight percent of carrier polymer. However, clearly the electrospinning of such solutions is not possible above a critical viscosity, where the surface tension is higher than the applied electrostatic force. Subianto et al. further studied the impact of the side chain length on the electrospinning of PFSA ionomers by comparing short-side-chain Aquivion ${ }^{\circledR}$ EW 830 and longside-chain Fumion ${ }^{\circledR}$ EW 900 [98?99]. At a given ionomer equivalent weight, the former has a 
higher volume concentration of sulfonic acid groups, and is more crystalline, than long side chain (LSC) PFSA. It was observed that the effect of the molecular weight of PEO was more marked when electrospinning the LSC ionomer, with a sharp transition between bead formation when using PEO of $\mathrm{M}_{\mathrm{w}} 400 \mathrm{kDa}$, and deposition of fibres with PEO of $\mathrm{M}_{\mathrm{w}} 1,000 \mathrm{kDa}$, whereas a continuous evolution from beaded to uniform fibres was observed when using PEO of increasing molecular weight on electrospinning SSC Aquivion ${ }^{\circledR}$. It was concluded that this is a result of weaker inter-chain interactions in LSC PFSA, which leads to a dispersion of lower viscosity. This assumption was further confirmed by the fact that using the same total polymer concentration of $20 \mathrm{wt} \%$ for both ionomers, the amount of PEO required for formation of electrospun fibres is significantly lower for Aquivion ${ }^{\circledR}$. Under these conditions Fumion ${ }^{\circledR}$ fibres are 350-600 $\mathrm{nm}$ in diameter, while Aquivion ${ }^{\circledR}$ forms thinner fibres with narrow size distribution (250-300 nm), which may be attributed to a more densely packed conformation of SSC ionomer during electrospinning, as well as to the higher PFSA:PEO ratio which favours thinner fibres. As previously observed for Nafion ${ }^{\circledR}$ [96], electrospinning SSC Aquivion ${ }^{\circledR}$ from solvents such as dimethylformamide, DMF, and dimethylacetamide, DMAc, resulted in a more stable polymer jet and produce nanofibres with good homogeneity. Their high dielectric constant and dipole moment enhance solution conductivity.

The problem of self-assembly/aggregation is not pronounced for sulfonated polyaromatic hydrocarbon polymers, which completely dissolve in various aprotic polar solvents such as DMF, DMAc, DMSO, etc. The possibility of electrospinning these ionomers depends solely on physical parameters such as molecular weight and the polymer volume fraction in solution. By carefully adjusting these parameters along with other processing parameters such surface tension of the solvent, distance between the source electrode and the target substrate, temperature, humidity, solution flow rate, applied voltage etc., electrospinning of these sulfonated polymers can be favoured over their electrospraying [88,100]. Various sulfonated 
aromatic polymer such as sulfonated polystyrene, sulfonated poly (arylene ether sulfone), sulfonated poly (ether ether ketone) have been electrospun into nanofibres without the use of any carrier polymer [100-107].

Several authors have reported that electrospun ionomers and sulfonated polymers present higher conductivity that dense membranes of the same polymer, and have suggested that this is due to a more ordered arrangement of proton conducting channels with longer channel lengths formed due to preferential orientation of polymer chains $[59,60,97,101,102]$. One of the most striking examples is the work of Elabd et al. who determined the proton conductivity of single Nafion ${ }^{\circledR}$ nanofibre (Figure 11 (a)) [97]. Values of $1.5 \mathrm{~S} / \mathrm{cm}$, which are an order of magnitude higher than the bulk membrane conductivity, were observed along single fibres of diameter 400 $\mathrm{nm}$. Interestingly, proton conductivity was found to be strictly related to the nanofibre diameter i.e. fibres with diameters $>2 \mu \mathrm{m}$ presented the conductivity similar to that of bulk Nafion ${ }^{\circledR}(\sim$ $0.1 \mathrm{~S} / \mathrm{cm})$ whereas fibres with diameters $<1 \mu \mathrm{m}$ exhibited a sharp increase in the conductivity with decreasing diameter as shown in Figure 11 (b). X-ray scattering provided evidence for the preferential alignment of inter-connected ionic aggregates along the fibre axis direction. This is an important observation that should be better exploited in the design of future fuel cell or electrolysis membranes. Indeed, when the same ionomer is used in the fibrous mat and in the matrix (e.g. poly (phthalazinone ether sulfone ketone) [108], sulfonated polyimide [59]), proton conductivity, swelling resistance and mechanical and thermal stability are increased and gas permeability decreased compared to the corresponding cast membranes, demonstrating the effect of « fiberisation ».

Choi et al. initiated the development of composite proton conducting membranes of PFSA/sulfonated aromatic polymer nanofibres impregnated with inert crosslinkable monomer [91,95,104,109]. Electrospun PFSA was impregnated with a UV-cross-linkable polyurethane resin using the following procedure: 1) Electrospinning of the ionomer into a nanofibre mat; 2) 
Densification of the mat under applied pressure to increase the volume density of the nanofibres; 3) Welding of the intersecting fibres thereby generating a 3D inter-connected pathways for proton conduction by exposure of the mat to vapours of a suitable solvent or by annealing; 4) Impregnation of the mat with an inert polymer [91,95]. The dependence of the proton conductivity at $80{ }^{\circ} \mathrm{C}$ on $\mathrm{RH}$, and stress-strain curves are shown in Figure 12 . The nanofibre-reinforced membranes demonstrated better mechanical properties than homogeneous membranes, which is attributed to the mechanical strength of the nanofibre morphology of the PFSA polymer as well as the reinforcing effect of the polyurethane. In addition, the proton conductivity of the composite membranes was higher than that of $\mathrm{Nafion}^{\circledR} 112$, which was ascribed to their higher charge density as well as expected formation of inter-connected 3D network of proton channels. Furthermore, gravimetric water swelling was lower than expected, based on the volume fraction of ionomer. Similar approaches have been employed by others to prepare composite membranes comprising electrospun ionomers with the pores filled by inert or charged polymers [59,110-121], and an summary overview is given in Table 3 .

As mentioned in the previous section, composite membranes elaborated by simultaneous electrospinning of both charged and inert polymers is another interesting approach (Figure 9) [84-86,122,123]. Dual nanofibre mats of Nafion ${ }^{\circledR}$ and polyphenylsulfone (PPSU) were fabricated and two types of composite membranes were obtained using different postelectrospinning treatments (Figure 8): 1) PPSU nanofibres dispersed in Nafion ${ }^{\circledR}$ matrix obtained by thermally annealing the Nafion ${ }^{\circledR}$ part of the dual mat, which then flows into the PPSU interfibre void space without destroying the PPSU fibre structure; 2) Nafion ${ }^{\circledR}$ nanofibres dispersed in PPSU matrix by exposing the PPSU part of the dual mat to chloroform vapour followed by thermal annealing resulting in filling of empty space between Nafion ${ }^{\circledR}$ nanofibres without harming the Nafion ${ }^{\circledR}$ fibre structure [84]. These membrane types presented similar proton 
conductivities that depended only on the Nafion ${ }^{\circledR}$ content, while the second membrane type presented superior mechanical properties.

\section{Composite membranes based on inorganic electrospun mats embedded in a polymer matrix}

Inorganic oxide and solid acid components such as metal oxides, zeolites, metal hydrogen phosphates and heteropolyacids have been incorporated in ionomer membranes, leading to an improvement in the proton conductivity under low $\mathrm{RH}[27,45,124]$ and a means of limiting the methanol crossover by increasing tortuosity [3,6,125]. Additionally, careful selection of inorganic materials based on their properties and morphologies can play a vital role in finetuning other properties, in particular increased mechanical strength and lower dimensional swelling [24]. In this context, the electrospinning of inorganic materials could be very valuable since it allows fabrication of homogeneously sized 1D nanostructures with tuned compositions and morphologies [126-131].

The incorporation of porous metal oxide $\left(\mathrm{TiO}_{2}, \mathrm{CeO}_{2}\right.$ and $\left.\mathrm{ZrO}_{1.95}\right)$ nanotubes produced by electrospinning into a Nafion $^{\circledR}$ membrane was an effective approach to enhance the conductivity under dry but also fully humid conditions [129,131]. Indeed, it was considered that the electrospun oxides increased membrane water retention, and also enhanced water diffusion due to their tubular morphology. At $18 \% \mathrm{RH}$ and $80{ }^{\circ} \mathrm{C}$, the Nafion-metal oxide nanotube composite membranes with optimum nanotube loading presented remarkably improved PEMFC performance as compared with a commercial Nafion ${ }^{\circledR} 212$ membrane (power density of Nafion-metal oxide nanotube composite membranes: $641 \mathrm{~mW} / \mathrm{cm}^{2}$ for the one with $1.5 \mathrm{wt} \% \mathrm{TiO}_{2}$ nanotube content, $449 \mathrm{~mW} / \mathrm{cm}^{2}$ for the one with $0.5 \mathrm{wt} \% \mathrm{CeO}_{2}$ nanotube content, $546 \mathrm{~mW} / \mathrm{cm}^{2}$ for the one with $1.5 \mathrm{wt} \% \mathrm{ZrO}_{2}$ nanotube content and $186 \mathrm{~mW} / \mathrm{cm}^{2}$ for Nafion ${ }^{\circledR}$ 
212 membrane). Furthermore, at $80{ }^{\circ} \mathrm{C}$ and various $\mathrm{RH}$ values, the $\mathrm{Nafion}-\mathrm{TiO}_{2}$ nanotube composite membranes always exhibited higher performance in compared to Nafion ${ }^{\circledR} 212$ and Nafion- $\mathrm{TiO}_{2}$ nanoparticle membranes, owing to the positive effect of the $1 \mathrm{D}$ hollow morphology on the water retention capacity of $\mathrm{TiO}_{2}$.

Thiam et al. developed a composite membrane of Nafion ${ }^{\circledR}$ and electrospun palladium-silica nanofibres [126]. The role of palladium in these membranes is to improve their water retention capacity and reduce their permeability towards methanol [132,133]. Figure 13 displays SEM images of electrospun Pd-silica nanofibres that show a smooth surface and a narrow distribution of fibre diameter and homogeneous dispersion of the nanofibres within the Nafion ${ }^{\circledR}$ matrix. A marked reduction in the methanol permeation was observed for the composite membranes owing to blockage of methanol transport channels by the $\mathrm{Pd} / \mathrm{SiO}_{2}$ nanofibres along with significant increase in membrane water uptake and proton conductivity, due to assistance by Si-OH groups in facilitating the construction of a 3D hydrogen bonding pathway for proton diffusion throughout the membrane. The composite membrane with 3 wt\% fibre content presented the best performance with proton conductivity of $129 \mathrm{mS} / \mathrm{cm}$ and methanol permeability of $8.36 \times 10^{-7} \mathrm{~cm}^{2} / \mathrm{s}$ in comparison to Nafion ${ }^{\circledR} 117$ with $98.3 \mathrm{mS} / \mathrm{cm}$ conductivity and $12.30 \times 10^{-7} \mathrm{~cm}^{2} / \mathrm{s}$ methanol permeability. Also, the presence of Pd nanoparticles is believed to help in the oxidation of permeated methanol and permit the diffusion of hydrogen allowing to keep a high conductivity [133].

An innovative route to the preparation of composite membranes using an electrospun inorganic mat involved utilisation of "reactive" co-axial electrospinning [128]. In this approach, the synthesis of the inorganic material occurs in situ, during the simultaneous electrospinning of the reactants from a coaxial needle. A zirconium precursor (zirconium propionate) and a phosphorus source (phosphorus pentoxide) were electrospun into a mat using a coaxial needle, the core and the sheath of the needle being fed by separate solutions. The reaction between 
components was initiated at the core/shell interface in the fibres that were then calcined and further treated with phosphoric acid to produce a zirconium hydrogen phosphate - zirconium oxide nanofibre mat. The composition throughout the fibres was determined to be homogeneous, indicating that reaction had propagated throughout the core/shell regions. Impregnation of this mat with Aquivion ${ }^{\circledR}$ SSC PFSA afforded a composite membrane with greater elastic modulus and yield point and increased proton conductivity than pristine, noncomposite Aquivion ${ }^{\circledR}$ membranes [128].

Alkali-metal and ammonium hydrogen sulfates, selenates and phosphates constitute one of the largest families of solid proton electrolytes. These compounds undergo a phase transition from a low-temperature phase to a superionic phase, characterised by a dynamically disordered hydrogen-bond network. Such compounds are of particular interest since they are proton conductive at temperatures in a range $\left(200-300{ }^{\circ} \mathrm{C}\right)$ where few materials are available and yet membrane development from them is difficult since they are inorganic salts. Recently, an interesting approach to produce a highly proton conducting nanofibre mat of caesium dihydrogen phosphate, $\mathrm{CsH}_{2} \mathrm{PO}_{4}(\mathrm{CDP})$ has been described [134], whereby $\mathrm{CDP}$ was thermally treated at a temperature higher than its super-protonic phase transition temperature, leading to its dehydration and partial polycondensation as per following reaction:

$\mathrm{CsH}_{2} \mathrm{PO}_{4}(\mathrm{~s}) \rightarrow \mathrm{CsH}_{2-2 \mathrm{x}} \mathrm{PO}_{4-\mathrm{x}}(\mathrm{s})+\mathrm{xH}_{2} \mathrm{O}(\mathrm{g}),(0<\mathrm{x} \leq 1)$

The resulting CDP-polymeric material consisting of chains of condensed phosphates was watersoluble and could be electrospun without a carrier polymer. SEM micrographs of freshly synthesised CDP particles, polymeric CDP and electrospun polymeric CDP are shown in Figure 14, where it may be seen that a highly inter-connected CDP-polymer nanofibre mat was formed. Its proton conductivity of $8 \times 10^{-3} \mathrm{~S} / \mathrm{cm}$ at $250{ }^{\circ} \mathrm{C}$ is close to that of the bulk. Although means have to be found to occlude the residual porosity without loss of the high temperature 
conductivity, the approach is one route to electrolyte membrane development for intermediate operating temperatures.

Yao et al. prepared electrospun highly conductive sulfated zirconia $\mathrm{S}-\mathrm{ZrO}_{2}$ combined with a cross-linked poly (2-acrylamido-2-methylpropane-sulfonic acid, C-PAMPS [116]. The proton conductivity of the membranes increased with decreasing fibre diameter due to increase in the number density of $\mathrm{S}-\mathrm{ZrO}_{2}$ fibres, which in turn increased the proportion of ionic channels, water uptake and ion exchange capacity (IEC). It also increased with $\mathrm{S}-\mathrm{ZrO}_{2}$ volume fraction owing to fibre induced inter-connected channels capable of anchoring water molecules and providing facile hopping pathways for proton transfer. S- $\mathrm{ZrO}_{2} / \mathrm{C}$-PAMPS hybrid membranes comprising $85 \mathrm{~nm}$ fibres and $30 \%$ fibre content shows proton conductivity of $3.4 \times 10^{-1} \mathrm{~S} / \mathrm{cm}$ at $100{ }^{\circ} \mathrm{C}$, much higher than that of previously reported C-PAMPS films or composite Nafion ${ }^{\circledR}$ membranes comprising $\mathrm{S}-\mathrm{ZrO}_{2}$ nanoparticles.

Another promising concept, developed by Laberty-Robert et al. [135-137], involves electrospinning of combined organic-inorganic precursor solutions to elaborate hybrid membranes which mimic the nanostructuration of $\mathrm{Nafion}^{\circledR}$ (i.e. phase separation between hydrophobic and hydrophilic domains at the scale from few nanometres up to several micrometres). The resulting hybrid membranes consists of an inorganic constituent ensuring proton conductivity and an organic constituent ensuring the mechanical robustness of the system. For instance, electrospinning of a sol-gel-based solution containing PVDF-HFP (polyvinylidenefluoride-hexafluoropropylene) and (2-(4-chlorosulfonylphenylethyltrichlorosilane (CSPTC) with tetraethylorthosilicate (TEOS) gave rise to an organic-inorganic hybrid membrane [136]. Such membrane presented a conductivity of $15 \mathrm{mS} / \mathrm{cm}$ at $120^{\circ} \mathrm{C}$ under $50 \%$ relative humidity and modulus much higher than that of Nafion ${ }^{\circledR}$ above $80{ }^{\circ} \mathrm{C}$. The intriguing properties of the organic-inorganic membrane is attributed to its microstructure 
consisting of bundled fibres (corresponding to assembly of small polymer fibres) surrounded by functionalised silica domains.

\section{Composite membranes of cross-linked electrospun mats embedded in a polymer matrix}

Cross-linking of polymer chains is a well-known strategy to produce robust and functional proton conducting membranes with enhanced thermal stability, mechanical properties, and reduced solubility [20]. Two typical cross-linking routes include (1) polymerisation of multifunctional monomer units with partial cross-linking during polymerisation (2) crosslinking of preformed polymer chains. The latter method allows facile processing and may be brought about through reaction along the polymer chain with bi-functional small molecule cross-linkers, a process which generally proceeds through mild and well-defined chemistry, but results in material that must be further purified to remove either catalyst or unreacted small molecules. Alternatively, cross-linking may be triggered externally by the application of heat, light, or pressure to generate highly reactive intermediates that undergo non-selective bond formation in an uncontrolled and ill-defined manner.

To date, only the second of the above routes has been explored to some extent in association with an electrospinning deposition step, where the cross-linked mat was the reinforcing or the ion conducting material. In particular, the polymer solution was mixed with a cross-linker molecule followed by electrospinning into a nanofibre mat and subsequent thermal treatment to induce the reaction $[120,137,138]$ or the polymer solution was electrospun into a nanofibre mat exposed to a cross-linker either in vapour or liquid form under required conditions $[65,140$ 143]. The latter of the above approaches was employed to prepare composite membranes of PFSA and polyvinylalcohol for DMFC and PEMFC applications. PVA is low cost and has lower methanol permeability than Nafion ${ }^{\circledR}$ by two orders of magnitude, but is water soluble, 
which results in limited dimensional stability of composite membranes reinforced with electrospun PVA [107]. To limit this solubility, electrospun PVA mats were exposed to glutaraldehyde vapour to induce cross-linking between -OH side groups. Impregnation of such cross-linked PVA nanofibre mats with Nafion ${ }^{\circledR}$ resulted in reduction in methanol permeability by an order of magnitude and enhanced mechanical strength in comparison to non-modified Nafion ${ }^{\circledR}$ membranes with similar thickness $[65,140,141]$.

Cross-linking of PFSA ionomers has been much investigated, although little reported on in the open literature, to avoid the problem of excessive swelling and mechanical deterioration of the corresponding membranes [3,125,144]. Cross-linked sulfonated polyaromatic membranes often suffer from brittleness due to the presence of covalent networks, and reduced proton conductivity due to utilisation of ionic functions in forming the cross-links. For this matter, electrospinning can help by providing a cross-linked ionomer membrane possessing good conducting properties along with reduced brittleness owing to flexible, interconnected network structure of the electrospun ionomer mat.

Anion-exchange membranes (AEMs) for alkaline fuel cells usually contain tetramethylammonium cationic fixed charge groups on a polymer backbone. To increase their ion conductivity the IEC should be increased by increasing the concentration of positively charged functional groups, which causes poor mechanical properties; the membrane suffers from excessive swelling when fully hydrated and polymer brittleness when dry. The development of novel AEMs passes through novel polymer chemistries and membrane architectures. Anion exchange membranes based on cross-linked electrospun fibres have been prepared by dual electrospinning [145-147]. For example, chloromethylated polysulfone (CMPSF) and PPSU have been co-electrospun from separate spinnerets, and the obtained mat submitted to partial cross-linking of the chloromethyl groups with an aliphatic diamine, followed by softening of the PPSU by solvent exposure to obtain a defect-free membrane [146]. 
Residual chloromethyl groups of the fibres were converted into tetramethylammonium ion exchange sites. The resulting composite membrane presented hydroxide ion conductivity of up to $65 \mathrm{mS} / \mathrm{cm}$ at $23{ }^{\circ} \mathrm{C}$ in water, with insolubility in water due to the presence of cross-links despite its high IEC $(3.1 \mathrm{mmol} / \mathrm{g})$.

Phosphoric acid doped polybenzimidazole (PBI) membranes provide high proton conductivity at ambient relative humidity up to $160^{\circ} \mathrm{C}$ and beyond, and are a viable and durable electrolyte for high temperature PEMFC (HT-PEMFC) [148,149]. Acid-imbibed PBI is prepared by immersion of PBI membranes in acid solutions. The uptake of phosphoric acid depends on the temperature of the acid bath and its concentration. Alternatively, $\mathrm{H}_{3} \mathrm{PO}_{4}-\mathrm{PBI}$ membranes are elaborated through a process whereby a polybenzimidazole polymer is prepared by a polycondensation reaction from its monomer components in polyphosphoric acid (PPA). After casting of the PBI-PPA solution, controlled hydrolysis of PPA to phosphoric acid leads directly to PBI membranes containing high quantities of $\mathrm{H}_{3} \mathrm{PO}_{4}$. In a third route, a membrane is cast from PBI dissolved in a mixture of phosphoric and polyphosphoric acids, followed by controlled hydrolysis of the PPA component. The membrane mechanical properties are strongly impacted by the number of acid molecules per PBI repeat unit (acid doping level), and it is important to find a means of improving mechanical strength and creep resistance for high acid doping level PBI membranes.

In one approach, polybenzimidazole and polybenzoxazine (PBz), a cross-linking agent, were electrospun [139] to give a PBz-modified PBI nanofibre mat which was thermally cross-linked via ring-opening addition reaction of benzoxazine groups, which allowed subsequent impregnation of the mat with PBI. The composite membrane resulted in high acid doping levels $(\approx 13)$ and dimensional stability upon acid doping. Figure 15 presents the stress-strain curves and the fuel cell performance $\left(\mathrm{H}_{2} / \mathrm{O}_{2}, 150{ }^{\circ} \mathrm{C}\right)$ of MEAs with the composite membranes with various wt $\%$ of $\mathrm{PBz}$ in comparison to neat PBI membrane. The membrane containing $10 \mathrm{wt} \%$ 
of cross-linking agent shows a 3-fold increase in Young's modulus $(6570 \pm 660 \mathrm{MPa})$ in comparison to neat PBI membrane, as well as a $34 \%$ increase of the fuel cell performance for the corresponding MEA (maximum power density of $670 \mathrm{~mW} / \mathrm{cm}^{2}$ ).

Rozière et al. have developed a means of cross-linking PBI membranes in a highly acid swollen state by incorporating a cross-linking molecule into a solution of PBI in phosphoric acid polyphosphoric acid [150]. Such membranes typically have an acid doping level of 16-25, and present a conductivity of $0.18 \mathrm{~S} / \mathrm{cm}$ at $160{ }^{\circ} \mathrm{C}$. By electrospinning the PBI-PPA solution containing the cross-linker, following by thermal curing, cross-linked PBI nanofibre reinforcements are obtained that are insoluble in DMAc and that can thus be used to reinforce highly acid doped PBI membranes. This approach has enabled improvement of the mechanical properties improved by a factor 25 compared to non-reinforced non-cross-linked acid doped polybenzimidazole membranes [151]. The current/voltage characteristics of MEAs incorporating an electrospun cross-linked PBI reinforced cross-linked PBI membrane are 640 $\mathrm{mV}$ at $0.2 \mathrm{~A} / \mathrm{cm}^{2}$ (hydrogen/air, atmospheric pressure) with a maximum power density of 500 $\mathrm{mW} / \mathrm{cm}^{2}$. Such membranes are of applicability not only in stationary fuel cell applications, but also as APUs or range extenders for electric vehicle applications. Applying a range extender protocol over a 1000 hour period led to a voltage loss of $<20 \mu \mathrm{V} / \mathrm{h}$.

\section{Concluding remarks and future trends}

Fuel cells are an integral part of future technologies for electrochemical energy conversion and storage, alongside water electrolysers, batteries and redox flow systems. With the Mirai fuel cell vehicle now commercialised by Toyota in major regions of the world and Hyundai and Honda following suit, fuel cells are a reality and already contribute to the move from fossil fuels for transport. Nevertheless, costs must be reduced and durability further improved, and 
the development of new materials with alternative compositions and novel architectures will help to meet these challenges.

This review has shown that electrospinning is showing great promise in the generation of materials for proton exchange membranes. This technique demonstrates great versatility and reproducibility, and it leads to the preparation of nanofibres with controlled size and morphology, as well as the possibility of exploiting different processing methodologies including coaxial and multiple needle electrospinning to generate designed structures. Furthermore, electrospinning will allow the up-scaled production of fibre materials for ionomer membranes with the perspective of industrial application.

The original morphologies, compositions and degrees of alignment of electrospun nanofibres lead to several advantageous features in composite fuel cell membranes based, amongst which, the possibility of reducing membrane thickness and area resistance, without losing mechanical strength. Issues that can arise in preparation of blend membranes by casting, such as interface and compatibility between different polymer components, may be overcome by dual needle electrospinning. Disassociating functions of mechanical strength and ion transport, and controlling phase separation by separating polymer phases or associating non-miscible polymers at designed length scales allow elaboration of ionomer membranes with high proton conductivity and high mechanical strenght. Further improvements are achievable by ionically or chemically cross-linking the electrospun and matrix components to further increase fuel cell lifetime. These accomplishments that lie mainly in the field of membranes for PEMFC are expected to allow the rapid development of complementary fuel cell technologies, such as alkaline and high temperature PEM fuel cells.

Despite these achievements, the full realisation of the potential of electrospinning in ionomer membranes is probably yet to come, as they are under assessment for industrialisation. Some challenges still remain, including the feasibility of electrospinning certain polymers, and 
attaining nanofibres of uniform and sufficiently low diameter, as well as better understanding of the correlation between morphology of electrospun material and processing parameters. Interfaces can be further adjusted and improved by associating reactive plasma, atomic layer deposition, electron beam or other surface modification techniques with electrospinning. A further challenge remains in the handling of ultrathin electrospun polymer nanofibre mats, but which can surely be overcome as the full benefits are further proven. An extension of the use of nanofibre based composite membranes and separators is also foreseen in other fields of electrochemical energy conversion and storage. A first step is their use in proton exchange membrane water electrolysers, and lithium ion batteries [53] while redox flow cells would also benefit from the approaches described in this review. In perspective, the realisation of an integrated membrane electrode assembly process fully based on electrospinning is an ambitious but realistic goal. 


\section{Figures and table captions}

Figure 1. Schematic representation of a Membrane Electrode Assembly (MEA).

Figure 2. Schematic illustration of a typical electrospinning set-up and the Taylor cone.

Figure 3. Number of published research articles in the period of 2005-2015 concerning (a). Electrospun materials for fuel cells (Web of Science data: Keywords: Electrospinning + Fuel cells); (b). Electrospun polymer electrolyte membranes for fuel cells (Web of Science data: Keywords: Electrospinning + Fuel cells refined with sub keywords polymer electrolyte membranes/proton exchange membranes).

Figure 4. Types of membrane architectures based on electrospun materials (a). a proton conducting polymer surrounding an electrospun mat of nanofibres of an inert reinforcing material, (b). an inert material surrounding a 3D interconnected mat of nanofibres of a proton conducting polymer, (c). an electrospun (proton conducting or non-conducting) inorganic mat embedded into a (proton conducting or non-conducting) polymer matrix, (d). a cross-linked electrospun polymer mat embedded in a polymer/inert matrix.

Figure 5: Nafion ${ }^{\circledR}$-impregnated electrospun composite PVDF membranes: (a). SEM image of the cross-section of the composite membrane containing $0.4 \mathrm{~g}$ of Nafion ${ }^{\circledR}$; (b). polarisation curves for the composite membranes with various weight contents of Nafion ${ }^{\circledR}$ and of Nafion ${ }^{\circledR}$ 115; reprinted with permission from reference 64, Copyright (2008) Elsevier.

Figure 6. Nafion ${ }^{\circledR}$ membrane with Nafion-functionalised PVDF nanofibres, Nafion ${ }^{\circledR}$ membrane with non-modified PVDF nanofibres (Nafion-CM2), commercial Nafion ${ }^{\circledR} 112$ and recast Nafion ${ }^{\circledR}$ (Nafion-RC) membranes: (a). Stress-strain curves; (b). Proton conductivities at different temperatures, adapted and reprinted with permission from reference 68, Copyright (2014) Royal Society of Chemistry. 
Figure 7: Wet-dry cycling at open-circuit-voltage at $85^{\circ} \mathrm{C}$ and $13 \% \mathrm{RH}$ for (a). PBI nanofibrereinforced chemically stabilised Aquivion ${ }^{\circledR}$ EW 700 membrane; (b). chemically stabilised Aquivion ${ }^{\circledR}$ EW 790 membrane (reference 83).

Figure 8. Photographs showing mechanical flexibility of sulfonic acid functionalised silicate (SS) glass electrolytes: (a). bulk SS-glass electrolyte; (b). membrane based on sulfonic acid functionalised silicate glass electrolyte embedded in polyimide matrix (memb-SS) after being subjected to various types of bending deformation; (c). memb-SS glass electrolyte after being subjected to the 100th bending cycle, where a strain rate was $50 \mathrm{~mm} / \mathrm{min}$. (d). A FE-SEM photograph demonstrating the structural stability of the memb-SS glass electrolyte after the 100th bending cycle, reprinted with permission from reference 67, Copyright (2013) American Chemical Society.

Figure 9. Fabrication of two types of nanofibre-composite Nafion ${ }^{\circledR} /$ poly(phenyl sulfone) membrane structures from the same dual fibre electrospun mat, reprinted with permission from reference 84, Copyright (2011) American Chemical Society.

Figure 10. SEM images of electrospun mats from $10 \mathrm{wt} \%$ solutions with different PFSA/PEO weight ratios $(75 / 25,90 / 10,95 / 5,99 / 1) ; 2 / 1$ wt ratio of 1-propanol/water as solvent for electrospinning. Fibre diameter distributions are shown in the histograms on the right, reprinted with permission from reference 91, Copyright (2010) Royal Society of Chemistry.

Figure 11: (a). SEM micrograph of a single high-purity Nafion ${ }^{\circledR}$ nanofibre bridging two electrodes; (b). proton conductivity versus fibre diameter for high-purity Nafion nanofibres measured on individual nanofibres (at $30{ }^{\circ} \mathrm{C}, 90 \% \mathrm{RH}$ ), reprinted with permission from reference 97, Copyright (2010) Royal Society of Chemistry.

Figure 12. (a). Dependence of in-plane proton conductivity on relative humidity at $80{ }^{\circ} \mathrm{C}$ for EW 733 PFSA and EW 825 PFSA nanofibre composite membranes and for Nafion ${ }^{\circledR} 212$; (b).Stress-strain curves of wet membrane samples at $25^{\circ} \mathrm{C}$; a: EW 733 PFSA homogeneous 
membrane, b: EW 825 PFSA homogeneous membrane, c: EW 733 PFSA nanofibre network membrane (0.70 fibre volume fraction), d: EW 825 PFSA nanofibre network membrane $(0.73$ fibre volume fraction) and e: UV-cross-linked NOA 63, adapted and reprinted with permission from reference 91, Copyright (2010) Royal Society of Chemistry.

Figure 13. SEM micrographs of: (a). Palladium-silica $\left(\mathrm{Pd}-\mathrm{SiO}_{2}\right)$ nanofibres; (b). Nafion ${ }^{\circledR}$ membrane comprising $3 \mathrm{wt} \%$ of $\mathrm{Pd}-\mathrm{SiO}_{2}$ nanofibres, adapted and reprinted with permission from reference 126, Copyright (2013) Elsevier.

Figure 14. SEM micrographs of (a) CDP, (b) polymeric CDP and (c) electrospun polymeric CDP, reprinted with permission from reference 134, Copyright (2013) Royal Society of Chemistry.

Figure 15. (a). Nanofibre-reinforced PBI composite membranes (PBI-CM-NF-PBz wt\%) and PBI: (a). Stress-strain curves; (b). Single cell fuel cell operation at $150{ }^{\circ} \mathrm{C}$ on dehumidified hydrogen-oxygen without gas back pressure, adapted and reprinted with permission from reference 136 Copyright (2013) Royal Society of Chemistry.

Table 1. Overview of proton conducting membranes of inert polymer based electrospun nanofibres and proton conducting electrolyte as matrix.

Table 2. Details of the electrospinning process and parameters associated with PFSA based polymers.

Table 3. Overview of proton conducting membranes comprising electrospun nanofibres of proton conducting electrolytes and a matrix of inert polymer. 


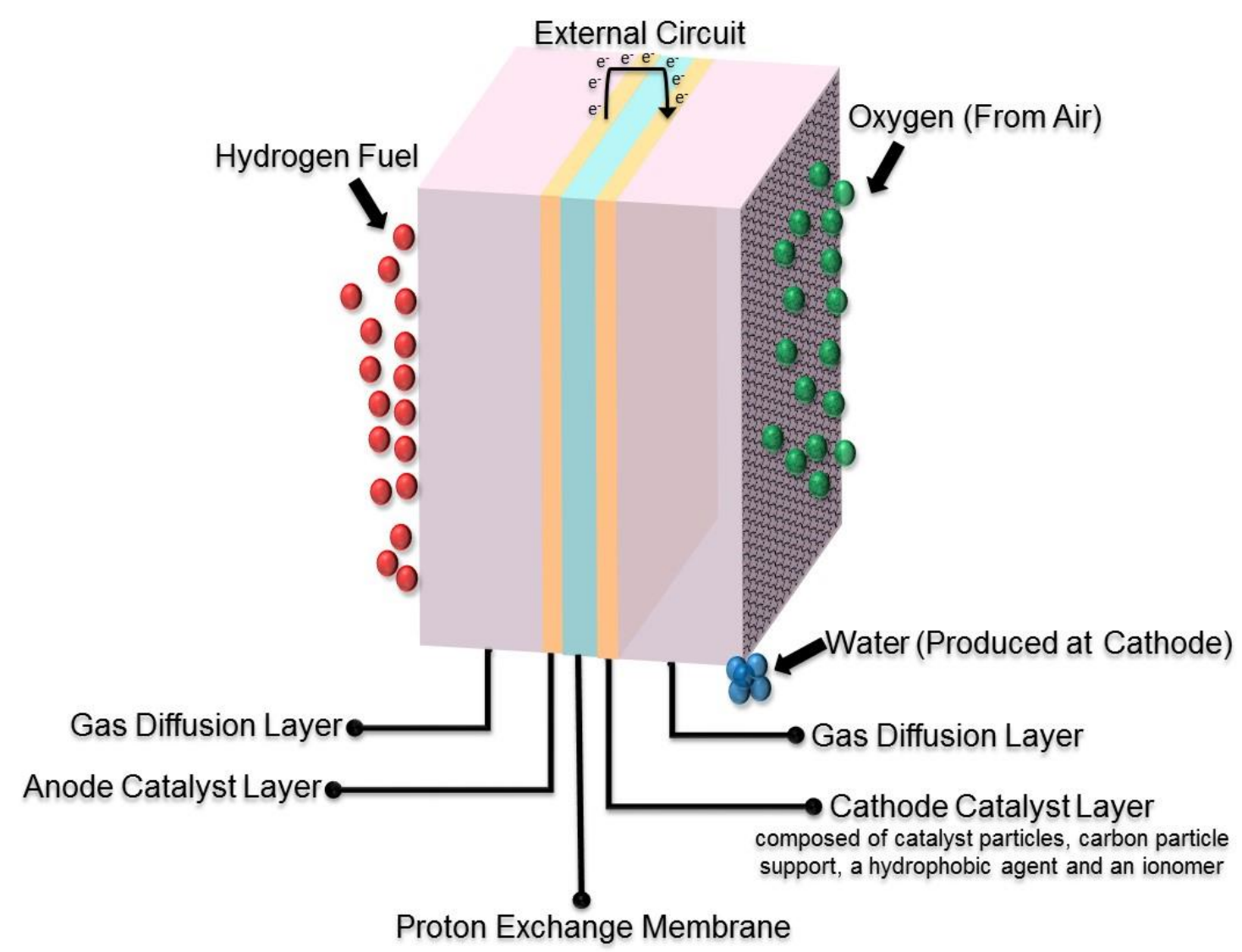

Figure 1: Schematic representation of a Membrane Electrode Assembly (MEA).

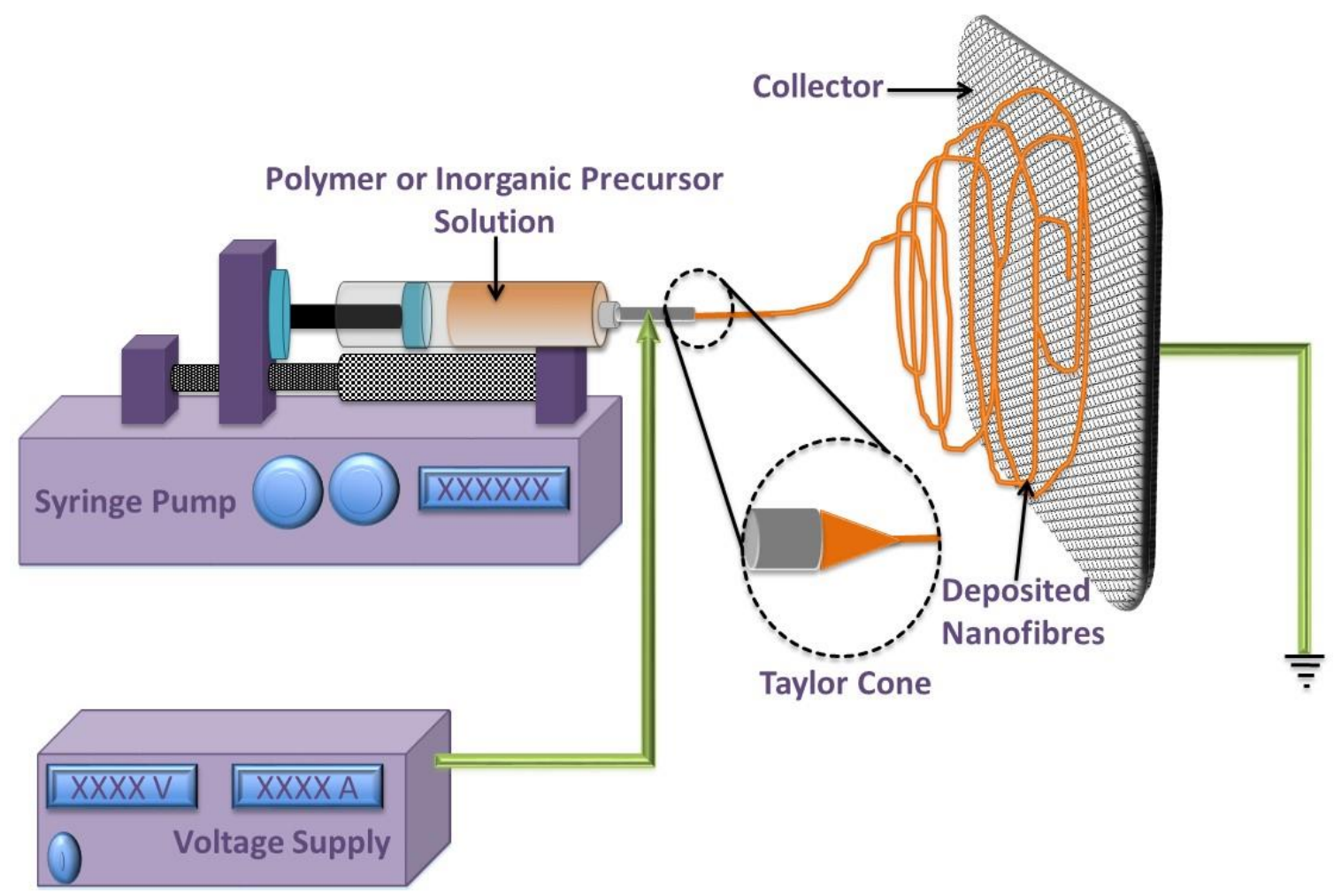


Figure 2: Schematic illustration of a typical electrospinning set-up and the Taylor cone.
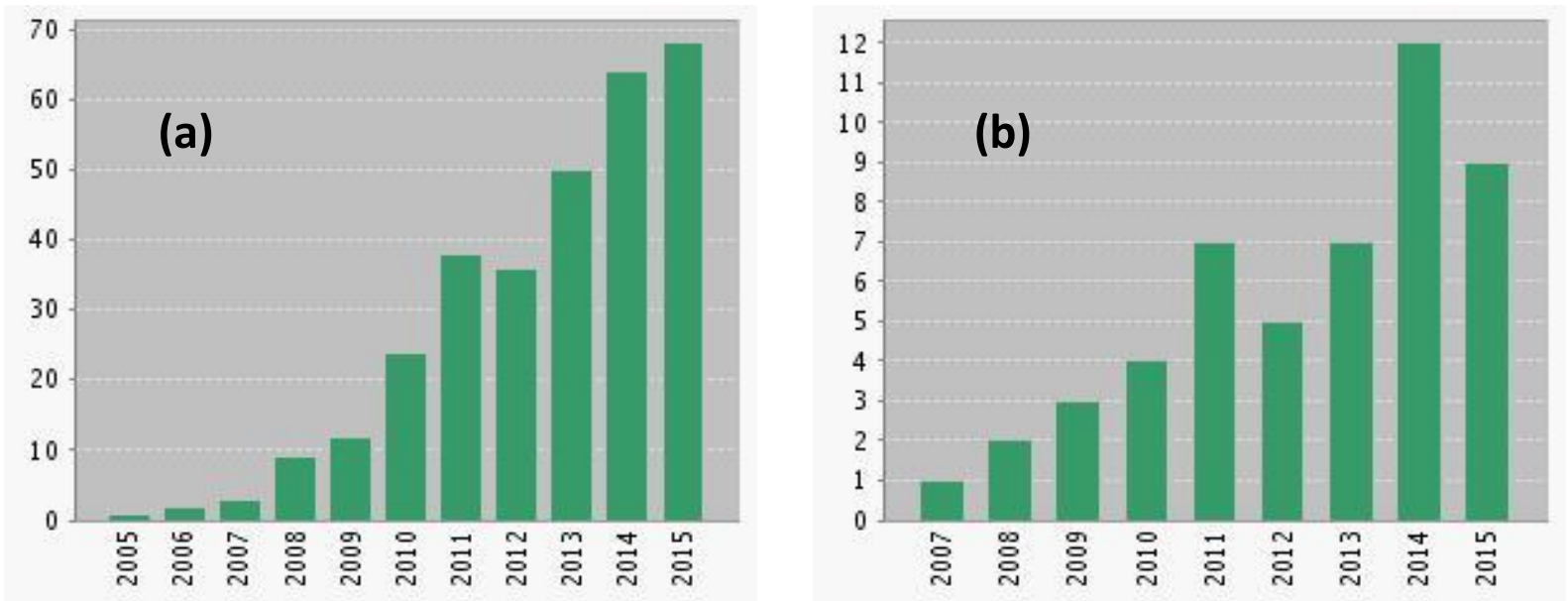

Figure 3: Number of published research articles in the period of 2005-2015 concerning (a). Electrospun materials for fuel cells (Web of Science data: Keywords: Electrospinning + Fuel cell); (b). Electrospun polymer membranes for fuel cells (Web of Science data: Keywords: Electrospinning + Fuel cell refined with sub keywords polymer electrolyte membrane/proton exchange membrane).
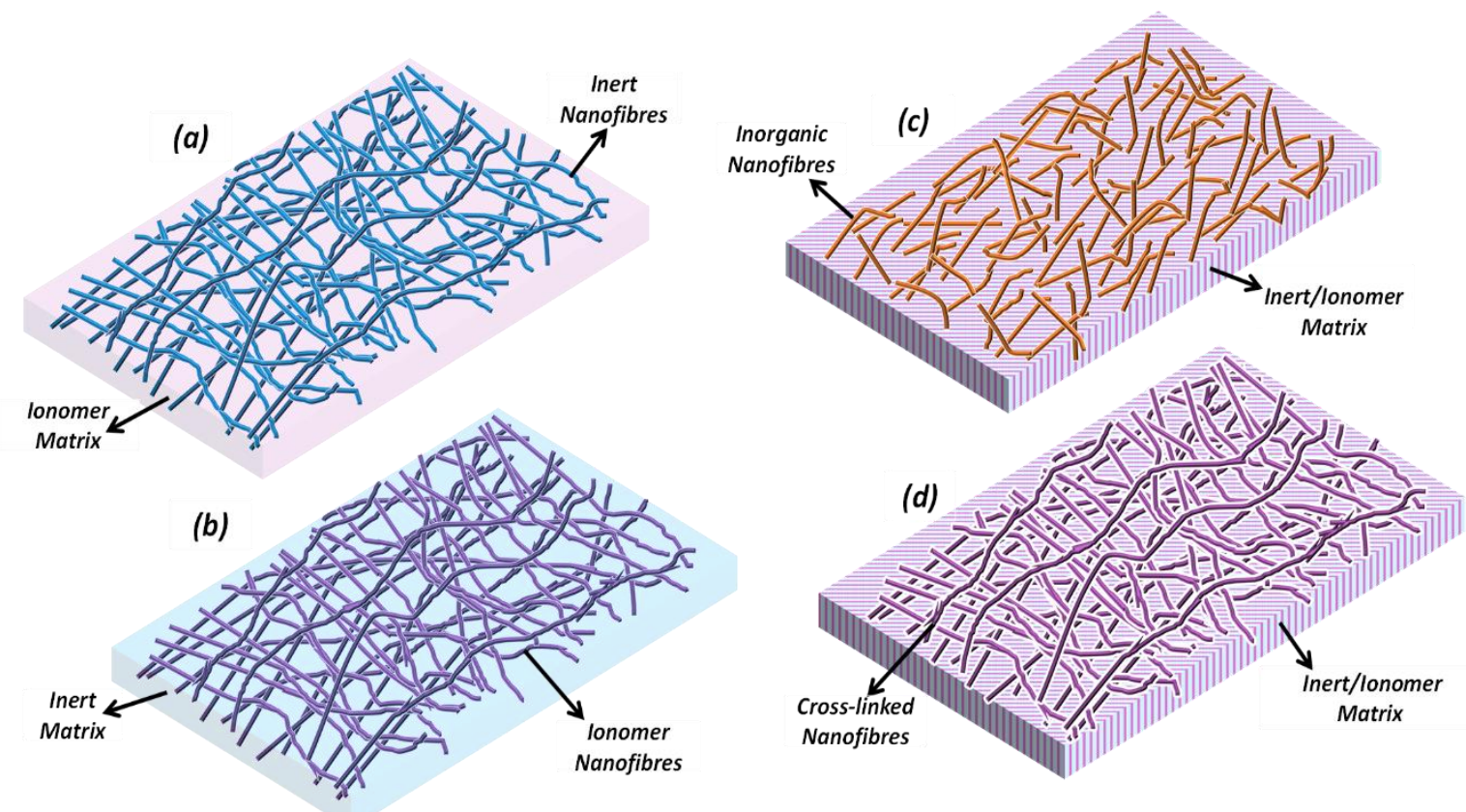
Figure 4: Types of membrane architectures based on electrospun materials (a). a proton conducting polymer surrounding an electrospun mat of nanofibres of an inert reinforcing material, (b). an inert material surrounding a 3D interconnected mat of nanofibres of a proton conducting polymer, (c). an electrospun (proton conducting or non-conducting) inorganic mat embedded into a (proton conducting or non-conducting) polymer matrix, (d). a cross-linked electrospun polymer mat embedded in a polymer/inert matrix.
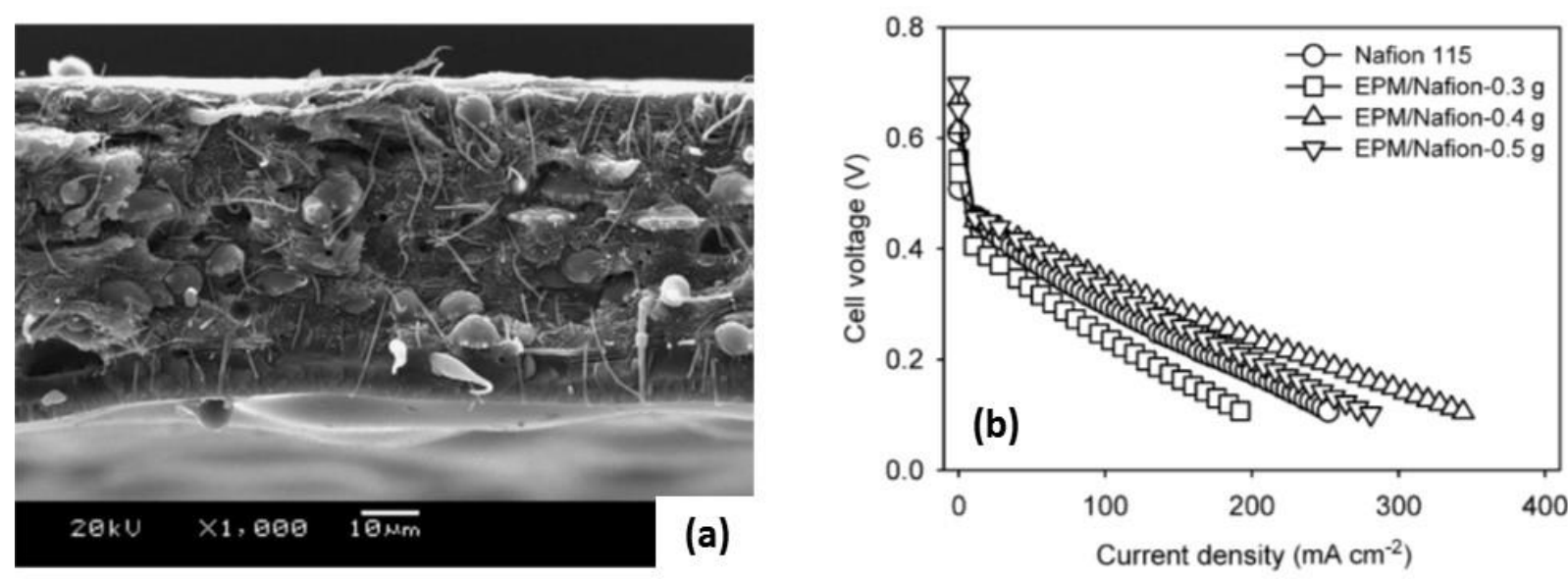

Figure 5: Nafion ${ }^{\circledR}$-impregnated electrospun composite PVDF membranes: (a). SEM image of the cross-section of the composite membrane containing $0.4 \mathrm{~g}$ of Nafion ${ }^{\circledR}$; (b). polarisation curves for the composite membranes with various weight contents of Nafion ${ }^{\circledR}$ and of Nafion ${ }^{\circledR}$ 115; reprinted with permission from reference 64, Copyright (2008) Elsevier. 

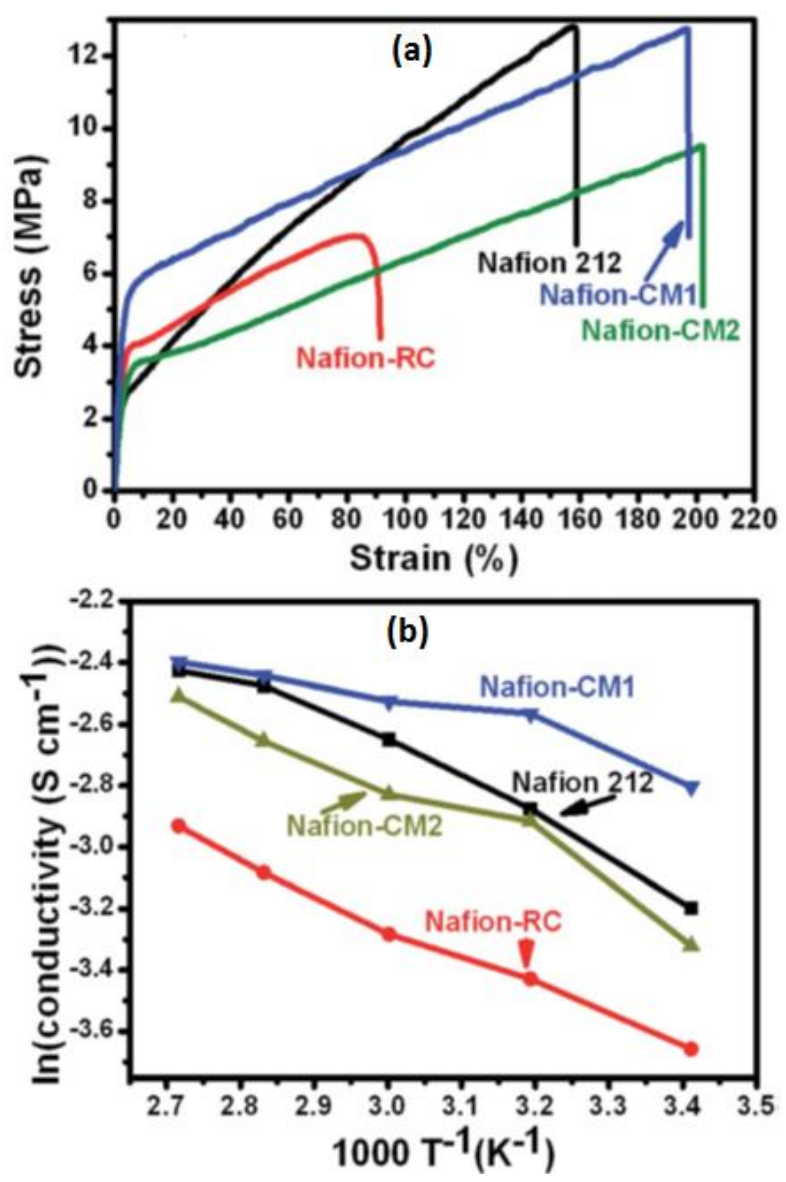

Figure 6: Nafion $^{\circledR}$ membrane with Nafion-functionalised PVDF nanofibres, Nafion ${ }^{\circledR}$ membrane with non-modified PVDF nanofibres (Nafion-CM2), commercial Nafion ${ }^{\circledR} 112$ and recast Nafion ${ }^{\circledR}$ (Nafion-RC) membranes: (a). Stress-strain curves; (b). Proton conductivities at different temperatures, adapted and reprinted with permission from reference 68, Copyright (2014) Royal Society of Chemistry. 


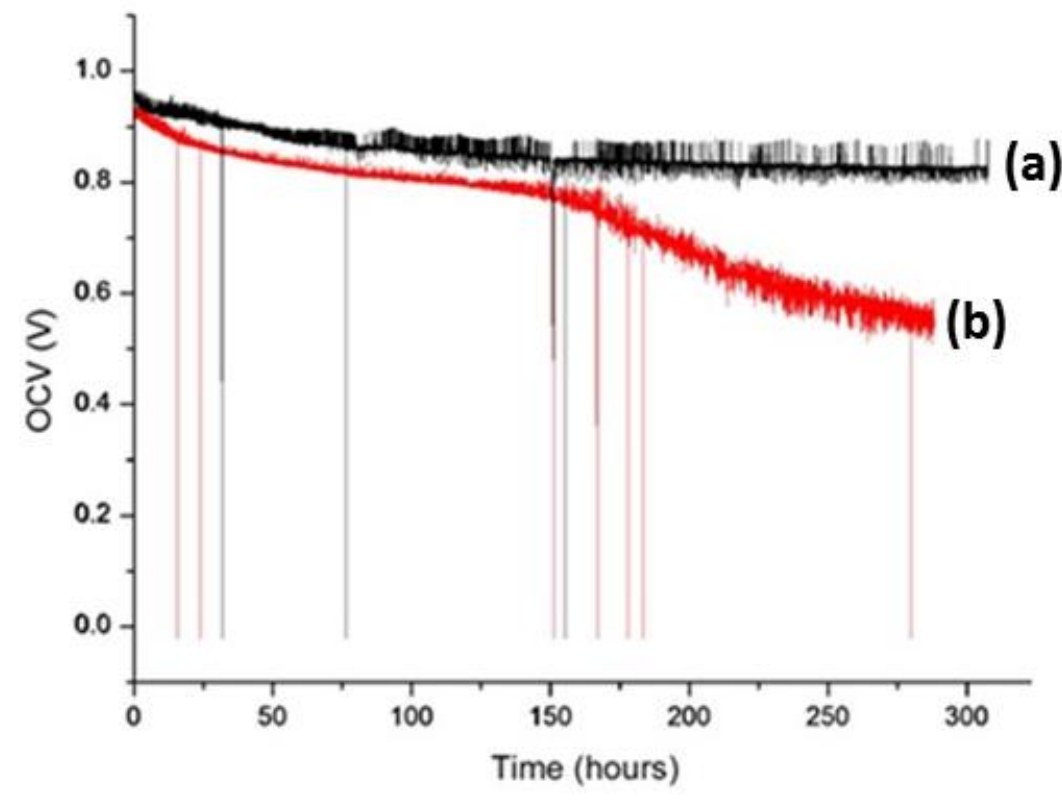

Figure 7: Wet-dry cycling at open-circuit-voltage at $85{ }^{\circ} \mathrm{C}$ and $13 \% \mathrm{RH}$ for (a). PBI nanofibrereinforced chemically stabilised Aquivion ${ }^{\circledR}$ EW 700 membrane; (b). chemically stabilised Aquivion ${ }^{\circledR}$ EW 790 membrane (reference 83).

(a)

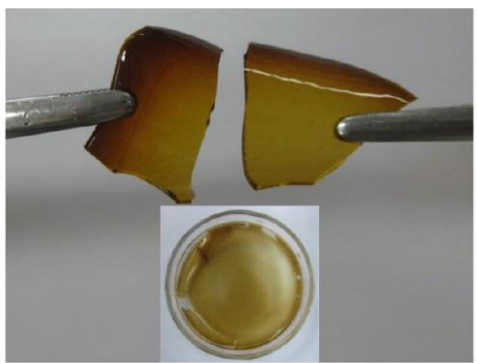

(b)

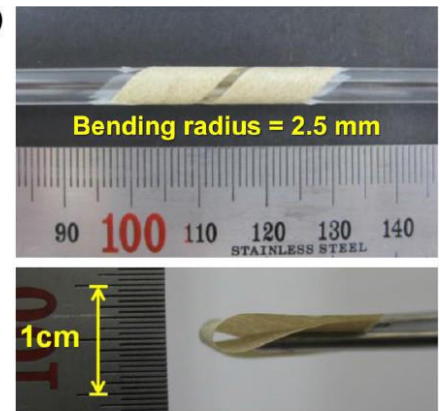

(d)

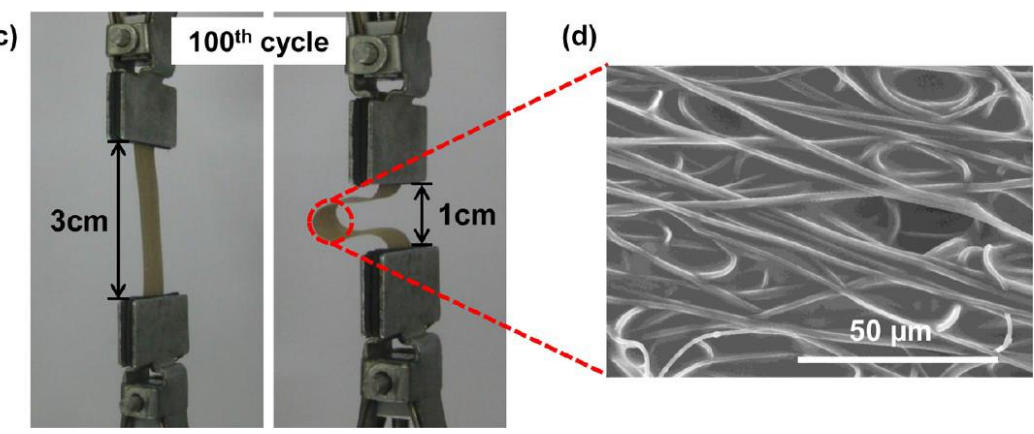

Figure 8: Photographs showing mechanical flexibility of sulfonic acid functionalised silicate (SS) glass electrolytes: (a). bulk SS-glass electrolyte; (b). membrane based on sulfonic acid 
functionalised silicate glass electrolyte embedded in polyimide matrix (memb-SS) after being subjected to various types of bending deformation; (c). memb-SS glass electrolyte after being subjected to the 100th bending cycle, where a strain rate was $50 \mathrm{~mm} / \mathrm{min}$. (d). A FE-SEM photograph demonstrating the structural stability of the memb-SS glass electrolyte after the 100th bending cycle, reprinted with permission from reference 67, Copyright (2013) American Chemical Society.

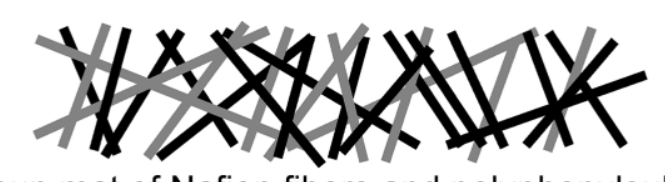

Electrospun mat of Nafion fibers and polyphenylsulfone fibers

(- Nafion; - polyphenylsulfone)

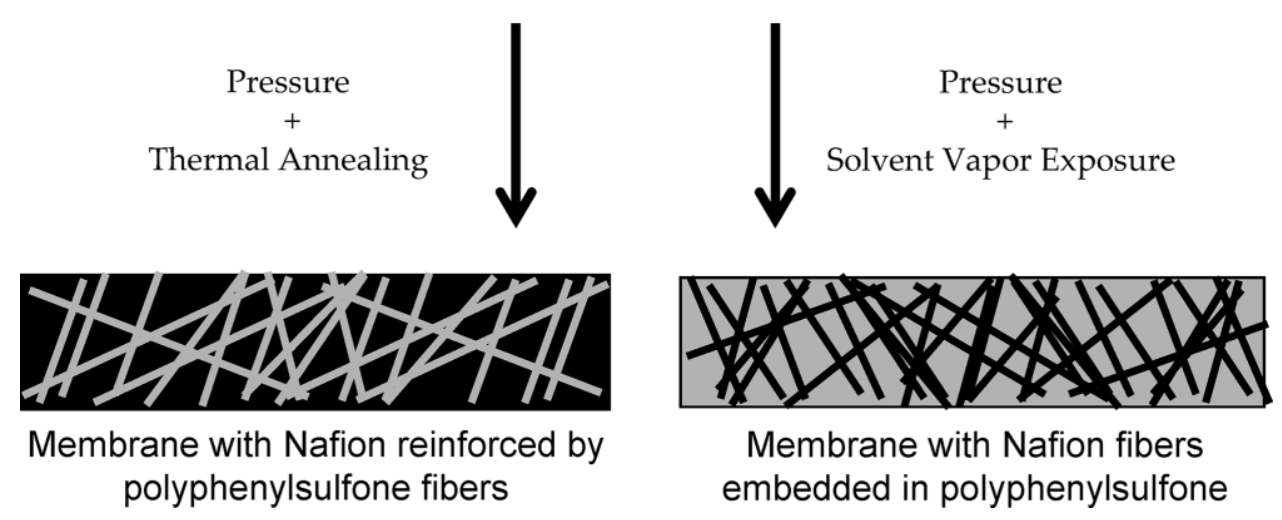

Figure 9: Fabrication of two types of nanofibre-composite Nafion/poly(phenyl sulfone) membrane structures from the same dual fibre electrospun mat, reprinted with permission from reference 84, Copyright (2011) American Chemical Society. 

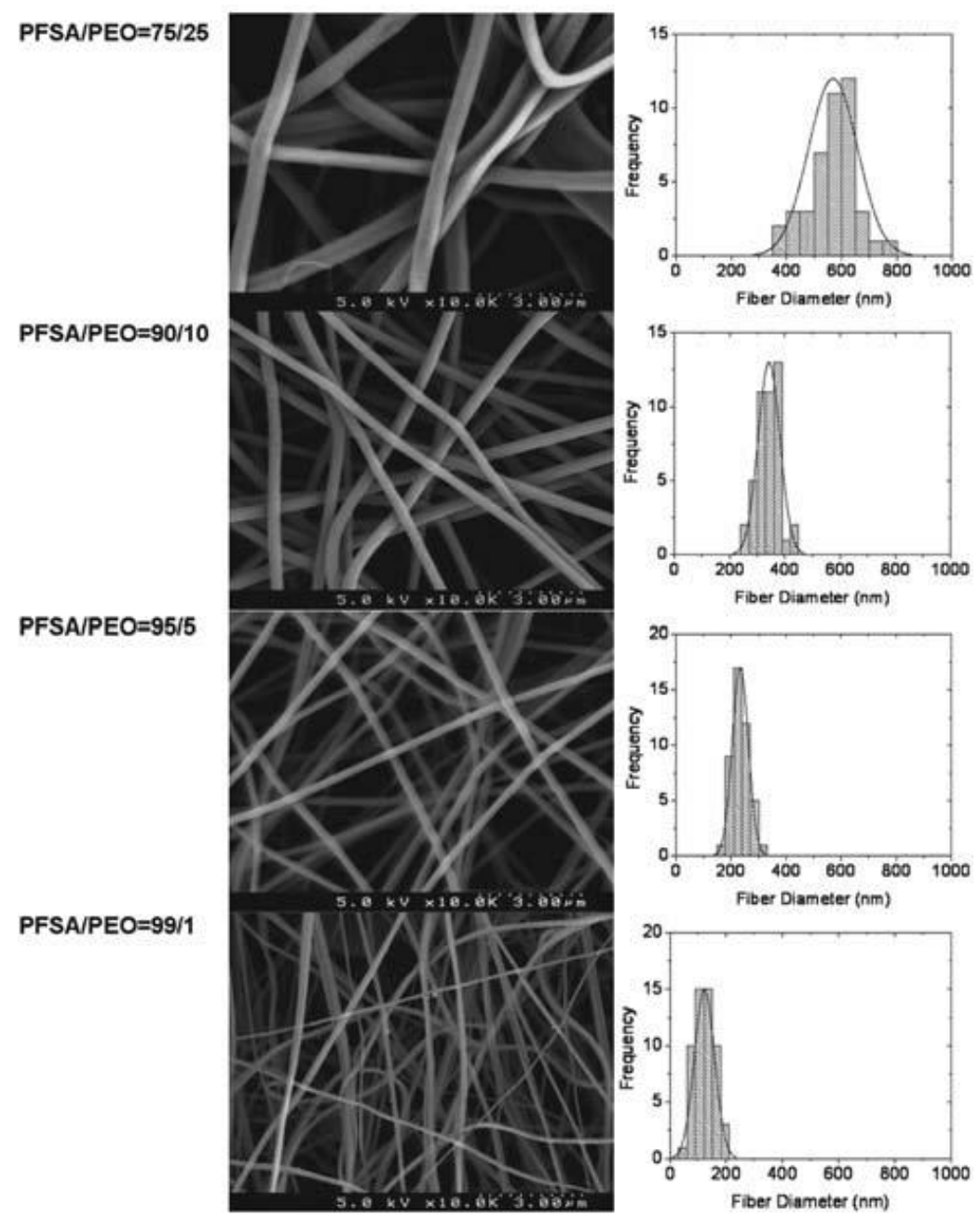

Figure 10: SEM images of electrospun mats from $10 \mathrm{wt} \%$ solutions with different PFSA/PEO weight ratios $(75 / 25,90 / 10,95 / 5,99 / 1) ; 2 / 1$ wt ratio of 1-propanol/water as solvent for electrospinning. Fibre diameter distributions are shown in the histograms on the right, reprinted with permission from reference 91, Copyright (2010) American Chemical Society. 

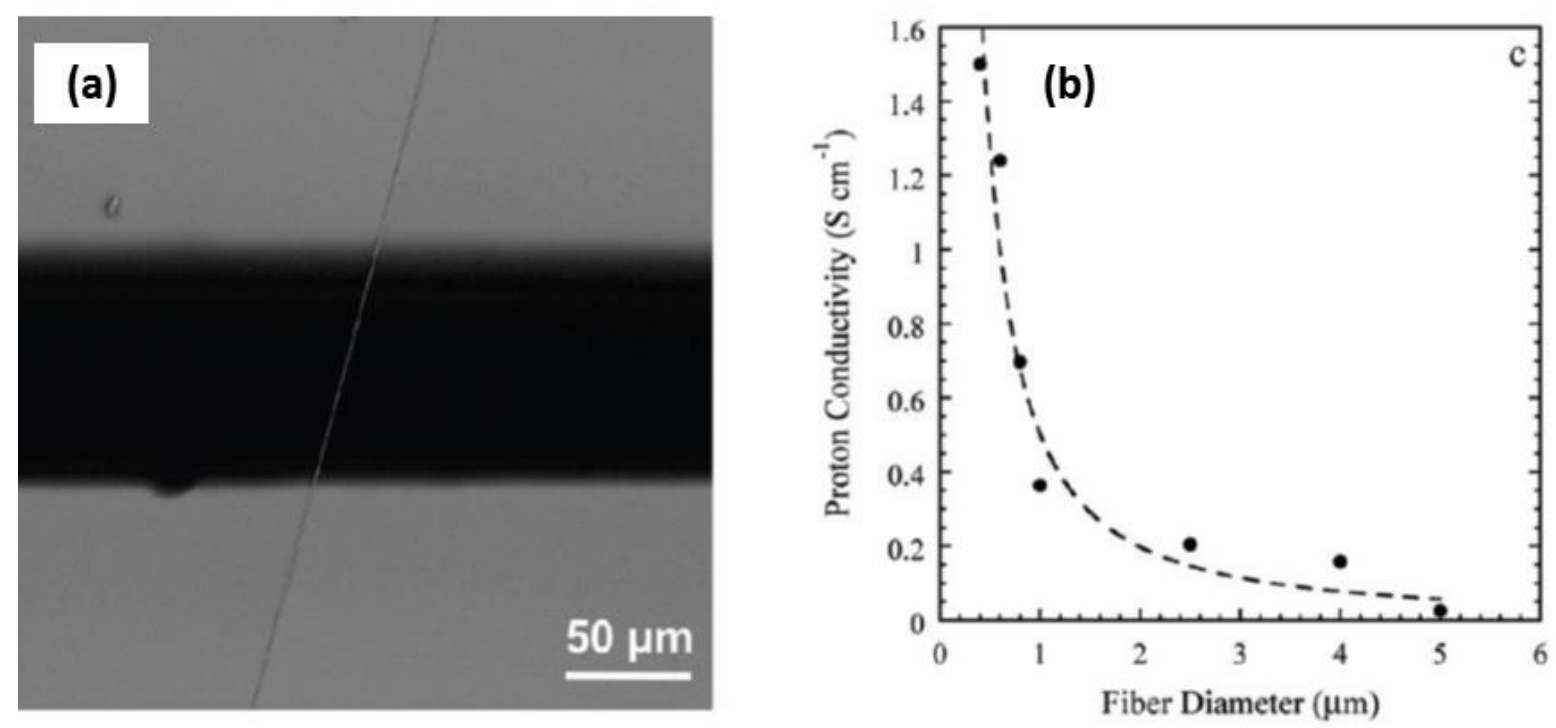

Figure 11: (a). SEM micrograph of a single high-purity Nafion ${ }^{\circledR}$ nanofibre bridging two electrodes; (b). proton conductivity versus fibre diameter for high-purity Nafion nanofibres measured on individual nanofibres (at $30{ }^{\circ} \mathrm{C}, 90 \% \mathrm{RH}$ ), reprinted with permission from reference 97, Copyright (2010) Royal Society of Chemistry.
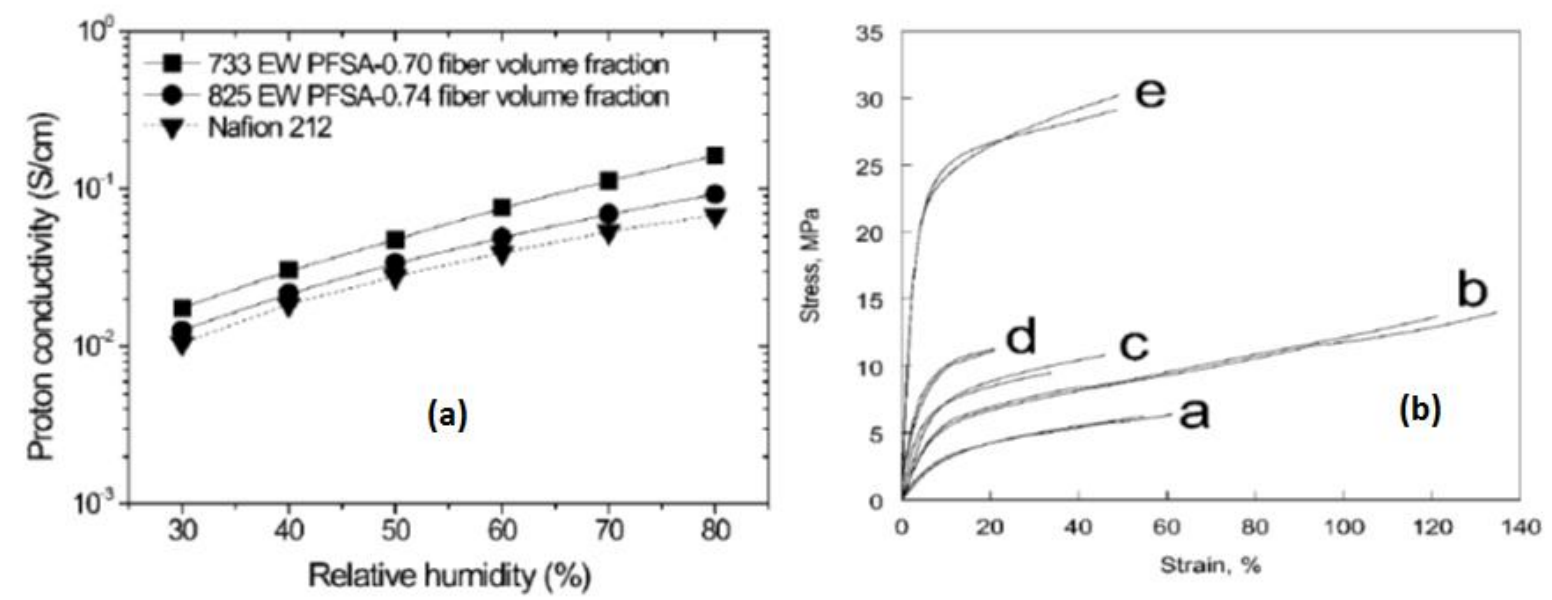

Figure 12: (a). Dependence of in-plane proton conductivity on relative humidity at $80{ }^{\circ} \mathrm{C}$ for EW 733 PFSA and EW 825 PFSA nanofibre composite membranes and for Nafion ${ }^{\circledR} 212$; (b).Stress-strain curves of wet membrane samples at $25^{\circ} \mathrm{C}$; a: EW 733 PFSA homogeneous 
membrane, b: EW 825 PFSA homogeneous membrane, c: EW 733 PFSA nanofibre network membrane (0.70 fibre volume fraction), d: EW 825 PFSA nanofibre network membrane $(0.73$ fibre volume fraction) and e: UV-cross-linked NOA 63, adapted and reprinted with permission from reference 91, Copyright (2010) Royal Society of Chemistry.
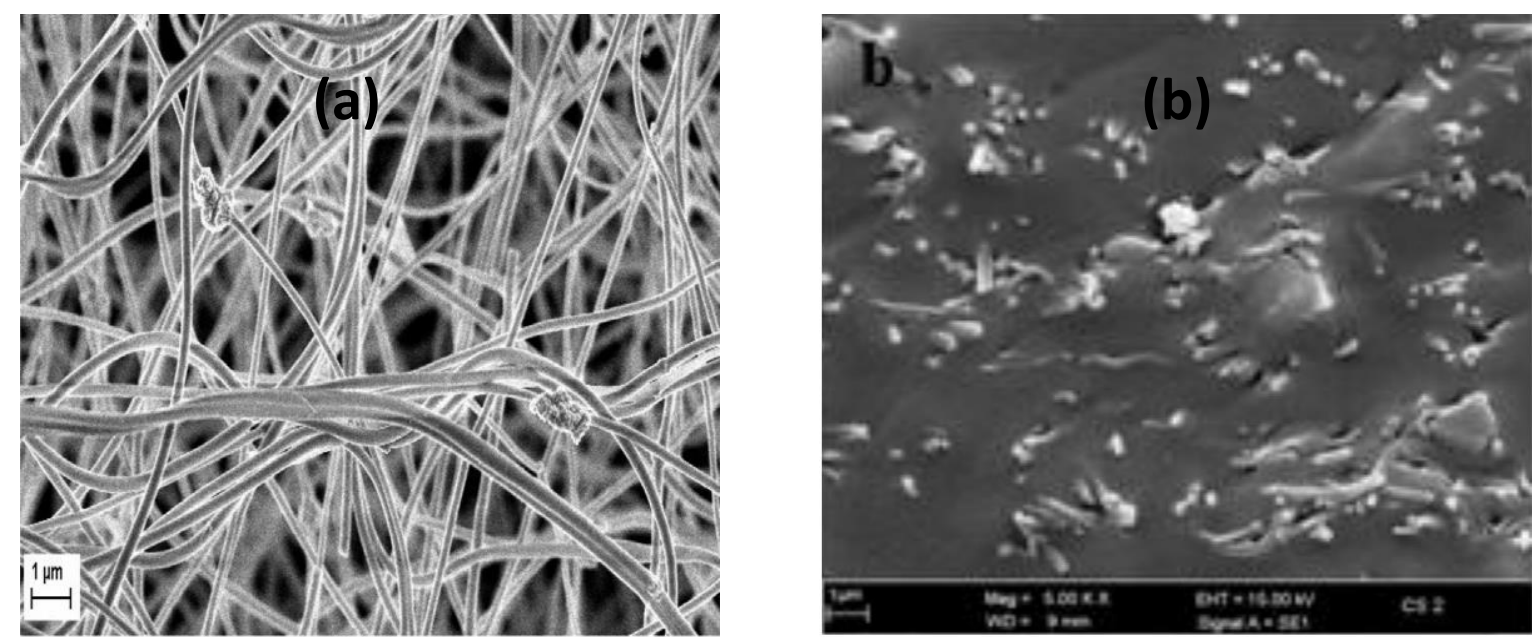

Figure 13: SEM micrographs of: (a). Palladium-silica $\left(\mathrm{Pd}-\mathrm{SiO}_{2}\right)$ nanofibres; (b). Nafion ${ }^{\circledR}$ membrane comprising $3 \mathrm{wt} \%$ of $\mathrm{Pd}-\mathrm{SiO}_{2}$ nanofibres, adapted and reprinted with permission from reference 126, Copyright (2013) Elsevier.
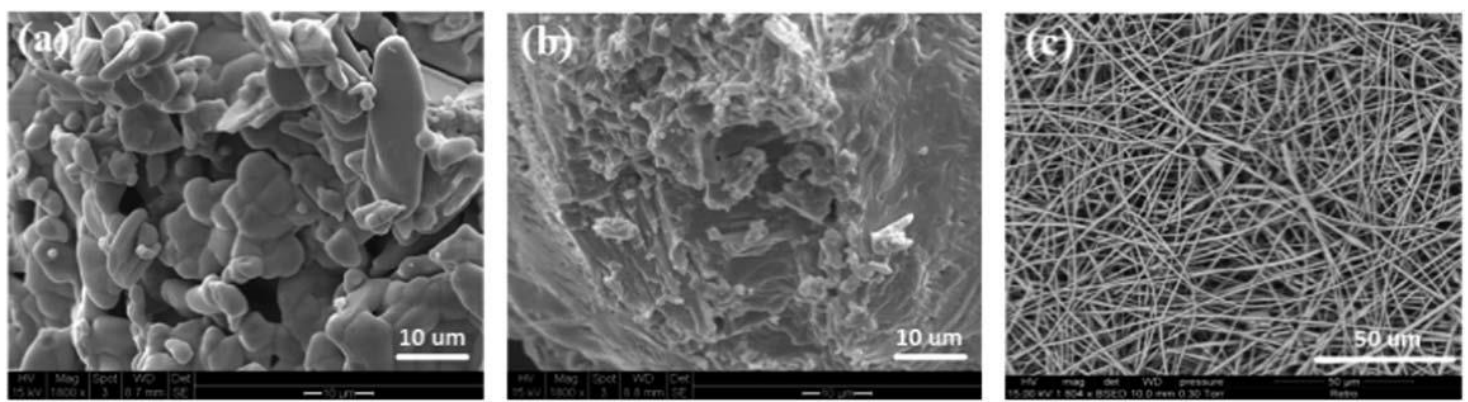

Figure 14: SEM micrographs of (a) CDP, (b) polymeric CDP and (c) electrospun polymeric CDP, reprinted with permission from reference 134, Copyright (2013) Royal Society of Chemistry. 

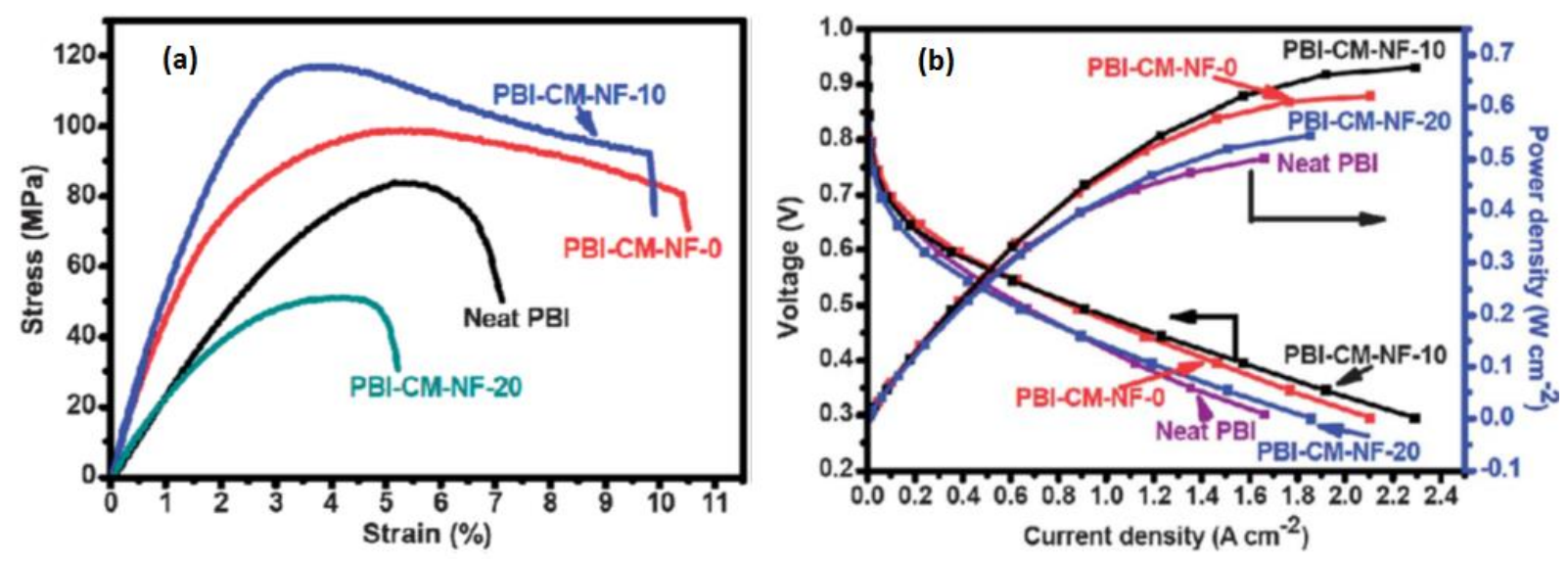

Figure 15: (a). Nanofibre-reinforced PBI composite membranes (PBI-CM-NF-PBz wt\%) and PBI: (a). Stress-strain curves; (b). Single cell fuel cell operation at $150{ }^{\circ} \mathrm{C}$ on dehumidified hydrogen-oxygen without gas back pressure, adapted and reprinted with permission from reference 139 Copyright (2013) Royal Society of Chemistry. 
Table 1: Overview of proton conducting membranes of inert polymer based electrospun nanofibres and proton conducting electrolyte as matrix.

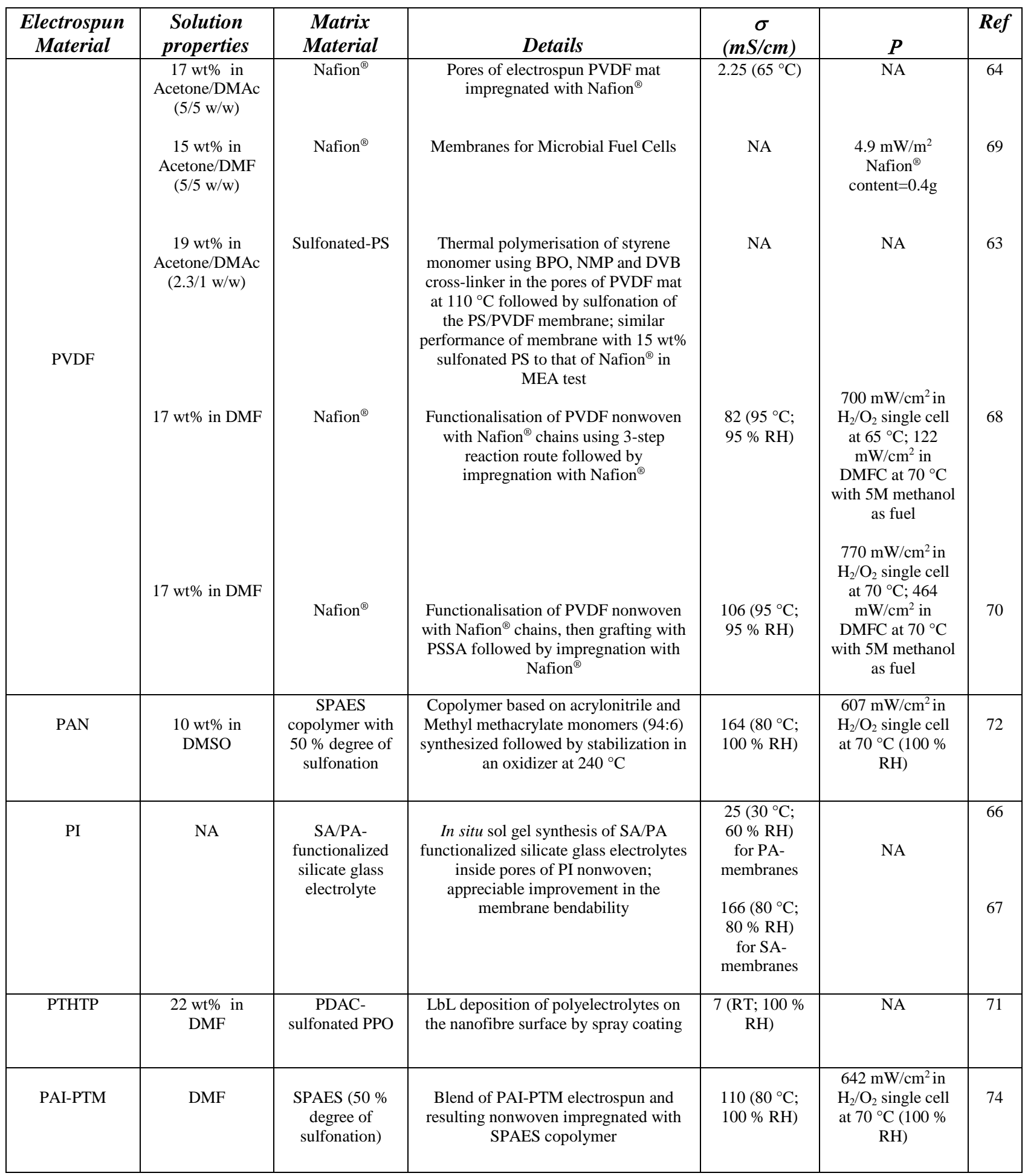


Table 2: Details of the electrospinning process and parameters associated with PFSA based polymers.

\begin{tabular}{|c|c|c|c|c|c|}
\hline $\begin{array}{c}\text { Electrospun } \\
\text { Material } \\
\end{array}$ & $\begin{array}{c}\text { Carrier Polymer/ } \\
\text { Additives }\end{array}$ & Solvent & Details & $\begin{array}{c}\sigma \\
(m S / c m)\end{array}$ & Ref \\
\hline Nafion ${ }^{\circledR}$ & $\begin{array}{c}5-28.6 \mathrm{wt} \% \text { PVA } \\
\mathrm{M}_{\mathrm{w}}: 2.0 \times 10^{5}\end{array}$ & IPA/Water & $\begin{array}{c}\text { Beaded nanofibres } \\
\text { obtained above } 13 \\
\text { wt } \% \text { PVA and } \\
\text { defect free } \\
\text { nanofibres } \\
\text { obtained at } 28.6 \\
\text { wt } \% \text { PVA }\end{array}$ & $\begin{array}{c}8.7-16 \\
\text { (equilibrated in } \\
\text { water for } 24 \mathrm{hrs} \text {; } \\
\text { RT } \\
\text { measurements) }\end{array}$ & 90 \\
\hline Nafion ${ }^{\circledR}$ & $\begin{array}{c}9-16.7 \mathrm{wt} \% \text { PEO } \\
\mathrm{M}_{\mathrm{w}}: 1.1 \times 10^{5}\end{array}$ & IPA/Water & $\begin{array}{c}\text { Defect free fibres } \\
\text { obtained at } 16.7 \\
\text { wt } \% \text { PEO }\end{array}$ & $\begin{array}{c}3.5-5.9 \\
\text { (conditions same } \\
\text { as above) }\end{array}$ & 90 \\
\hline Nafion $^{\circledR}$ & $\begin{array}{l}\text { 5-66 wt } \% \text { PAA } \\
\mathrm{M}_{\mathrm{w}}: 4.5 \times 10^{5}\end{array}$ & IPA/Water (3/1) & $\begin{array}{c}\text { Beaded- } \\
\text { nanofibres } \\
\text { obtained above } 12 \\
\text { wt } \% \text { PAA and } \\
\text { defect free fibres } \\
\text { obtained at } 25 \\
\text { wt } \% \text { PAA }\end{array}$ & NA & 94 \\
\hline Nafion ${ }^{\circledR}$ & $\begin{array}{c}2-5 \mathrm{wt} \% \text { PEO } \\
\mathrm{M}_{\mathrm{w}}: 5 \times 10^{6} \mathrm{~g} / \mathrm{mol}\end{array}$ & Ethanol/Water & $\begin{array}{l}\text { Fibres with } \\
\text { average diameter } \\
\text { of } \sim 150 \mathrm{~nm}\end{array}$ & NA & 92 \\
\hline Nafion ${ }^{\circledR}$ & $\begin{array}{l}1-2 \mathrm{wt} \% \text { PEO } \\
\mathrm{M}_{\mathrm{w}}: 300 \mathrm{kDa}\end{array}$ & IPA/Water (3/1) & $\begin{array}{c}\text { Well-formed } \\
\text { nanofibre mats } \\
\text { with diameter } \\
\text { between } 300 \text { and } \\
900 \mathrm{~nm} \text { by using } \\
1 \mathrm{wt} \% \text { PEO }\end{array}$ & NA & 96 \\
\hline Nafion ${ }^{\circledR}$ & $\begin{array}{c}0.1-2 \mathrm{wt} \% \text { PEO } \\
\mathrm{M}_{\mathrm{w}}: 8000 \mathrm{~kg} / \mathrm{mol}\end{array}$ & Methanol & $\begin{array}{c}\text { High purity } \\
\text { nanofibres with } \\
400 \mathrm{~nm} \text { diameter } \\
\text { by using } 0.1 \mathrm{wt} \% \\
\text { PEO }\end{array}$ & $\begin{array}{c}1500\left(30^{\circ} \mathrm{C} ; 90\right. \\
\% \mathrm{RH})\end{array}$ & 97 \\
\hline $\begin{array}{l}\text { PFSA ionomer } \\
\text { pellets }\end{array}$ & $\begin{array}{l}8-50 \mathrm{wt} \% \text { PVP } \\
\mathrm{M}_{\mathrm{w}}: 1.3 \times 10^{6}\end{array}$ & DMF & $\begin{array}{c}\text { Defect-free } \\
\text { nanofibre mats } \\
\text { with diameter } \\
\text { between } 100 \text { and } \\
400 \mathrm{~nm} \text { by using } \\
8 \mathrm{wt} \% \text { PVP }\end{array}$ & NA & 93 \\
\hline Aquivion $^{\circledR}$ & $\begin{array}{c}1 \mathrm{wt} \% \text { PEO } \\
\mathrm{M}_{\mathrm{w}}: 6000-1.0 \times 10^{6} \\
\mathrm{Da}\end{array}$ & $\begin{array}{l}\mathrm{DMAc}_{(\mathrm{H}} \mathrm{H}_{2} \mathrm{O} \\
\quad(99 / 1)\end{array}$ & $\begin{array}{c}\text { Nanofibre } \\
\text { diameter around } \\
300 \mathrm{~nm}\end{array}$ & $\begin{array}{c}97\left(80{ }^{\circ} \mathrm{C} ; 95 \%\right. \\
\mathrm{RH}) \\
66\left(120^{\circ} \mathrm{C} ; 95 \%\right. \\
\mathrm{RH})\end{array}$ & 98 \\
\hline Fumion ${ }^{\circledR}$ & $\begin{array}{c}1.5 \mathrm{wt} \% \text { PEO } \\
\mathrm{M}_{\mathrm{w}}: 6000-1.0 \times 10^{6} \\
\mathrm{Da}\end{array}$ & DMAc & $\begin{array}{c}\text { Short side chain } \\
\text { ionomers present } \\
\text { higher } \\
\text { crystallinity }\end{array}$ & $\begin{array}{c}58\left(80{ }^{\circ} \mathrm{C} ; 95 \%\right. \\
\mathrm{RH}) \\
54\left(120^{\circ} \mathrm{C} ; 95 \%\right. \\
\mathrm{RH})\end{array}$ & 98 \\
\hline
\end{tabular}


Table 3: Overview of proton conducting membranes comprising electrospun nanofibres of proton conducting electrolytes and a matrix of inert polymer.

\begin{tabular}{|c|c|c|c|c|c|}
\hline $\begin{array}{c}\text { Electrospun } \\
\text { Material }\end{array}$ & $\begin{array}{c}\text { Solution } \\
\text { properties }\end{array}$ & $\begin{array}{c}\text { Matrix } \\
\text { Material }\end{array}$ & Details & $\begin{array}{c}\sigma \\
(\mathrm{mS} / \mathrm{cm})\end{array}$ & $\operatorname{Ref}$ \\
\hline SPAES & $\begin{array}{l}25 \mathrm{wt} \% \text { in } \\
\text { DMAc }\end{array}$ & NOA 63 & $\begin{array}{c}\text { Densified SPAES mats } \\
\text { imbibed with NOA } 63 \\
\text { followed by UV cross- } \\
\text { linking of NOA }\end{array}$ & $\begin{array}{c}86\left(25^{\circ} \mathrm{C} ; 100 \%\right. \\
\text { RH) for } 70 \mathrm{wt} \% \\
\text { SPES content }\end{array}$ & 104 \\
\hline $\begin{array}{l}\text { PFSA ionomer } \\
\text { (3M corporation) }\end{array}$ & $\begin{array}{c}20 \mathrm{wt} \% \text { of } 825 \\
\text { EW PFSA in } \\
\text { propanol/water } \\
(2 / 1 \mathrm{w} / \mathrm{w}) \\
\\
42.5 \mathrm{wt} \% \text { of } 733 \\
\text { EW PFSA in } \\
\text { methanol/water } \\
(4 / 1 \mathrm{w} / \mathrm{w}) \text { for } \\
0.3-1 \mathrm{wt} \% \\
\\
\text { PEO as carrier } \\
\text { polymer }\left(\mathrm{M}_{\mathrm{w}} \text { : }\right. \\
\left.10^{6} \mathrm{Da}\right)\end{array}$ & NOA 63 & $\begin{array}{l}\text { Defect-free PFSA mats } \\
\text { imbibed with NOA } 63 \\
\text { followed by UV cross- } \\
\text { linking of NOA; } \\
\text { Removal of carrier } \\
\text { polymer by boiling in } \\
1 \mathrm{M} \mathrm{H}_{2} \mathrm{SO}_{4} \text { solution and } \\
\text { in DI water for one hour } \\
\text { each time. }\end{array}$ & $\begin{array}{c}160\left(80{ }^{\circ} \mathrm{C} ; 80 \%\right. \\
\mathrm{RH}) \text { for PEM } \\
\text { with } \\
733 \text { EW PFSA }\end{array}$ & 91 \\
\hline SPES & $25 \mathrm{wt} \%$ in DMF & Nafion $^{\circledR}$ & $\begin{array}{c}\text { Bead-free SPES } \\
\text { nanofibre mat } \\
\text { impregnated with } \\
\text { Nafion }{ }^{\circledR} \text { solution; } \\
\text { Significant reduction in } \\
\text { nanofibre diameter due } \\
\text { to sulfonation of SPES }\end{array}$ & $\begin{array}{c}87.5\left(25^{\circ} \mathrm{C} ; 95 \%\right. \\
\mathrm{RH}) \text { for } 70 \mathrm{wt} \% \\
\text { SPES content }\end{array}$ & 119 \\
\hline $\begin{array}{c}\text { Poly (ether } \\
\text { sulfone) (PES) } \\
\text { and PFSA resin } \\
\text { (PFSA-Na) Blend } \\
(1 / 1 \mathrm{w} / \mathrm{w})\end{array}$ & $\begin{array}{l}20 \text { wt } \% \text { in } \\
\text { DMAc with } \\
0-12 \text { wt } \% \text { Non- } \\
\text { solvent NS } \\
\text { (Ethanol or } \\
\text { IPA) }\end{array}$ & - & $\begin{array}{l}\text { Increase in average } \\
\text { diameter and decrease in } \\
\text { hydrophobicity of } \\
\text { electrospun PES/PFSA- } \\
\text { Na nanofibres with } \\
\text { increasing NS content }\end{array}$ & NA & 105 \\
\hline $\begin{array}{l}\text { SPAES and } \\
\text { sPOSS Blend } \\
(60 / 40 \mathrm{w} / \mathrm{w})\end{array}$ & $\begin{array}{l}40 \mathrm{wt} \% \text {. in } 2- \\
\text { butoxyethanol }\end{array}$ & NOA 63 & $\begin{array}{l}\text { Densified and welded } \\
\text { mat imbibed with NOA } \\
63 \text { followed by UV } \\
\text { cross-linking of NOA }\end{array}$ & $\begin{array}{l}94\left(30^{\circ} \mathrm{C} ; 80 \%\right. \\
\mathrm{RH}) \text { for } 70 \mathrm{vol} \% \\
\text { nanofibre fraction }\end{array}$ & 110 \\
\hline $\begin{array}{c}\text { PFSA ionomer } \\
(3 \mathrm{M} \text { corporation) } \\
\text { and } \\
\text { PPSU }\end{array}$ & $\begin{array}{c}20 \mathrm{wt} \% \text { of } 660 \\
\text { EW PFSA in } \\
\text { propanol/water } \\
(2 / 1 \mathrm{w} / \mathrm{w}) ; 0.3 \\
\text { wt } \% \mathrm{PEO}\left(\mathrm{M}_{\mathrm{w}} \text { : }\right. \\
\left.10^{6} \mathrm{Da}\right) \\
\\
\text { Sol. of PPSU in } \\
\text { NMP/acetone } \\
(4 / 1 \mathrm{w} / \mathrm{w})\end{array}$ & - & $\begin{array}{l}\text { Dual mat obtained by } \\
\text { co-electrospinning of } 72 \\
\text { vol } \% \text { PFSA and } 28 \\
\text { vol } \% \text { PPSU solutions } \\
\text { followed by softening } \\
\text { and flowing of PFSA } \\
\text { ionomer into PPSU } \\
\text { inter-fibre space }\end{array}$ & $\begin{array}{c}93\left(120^{\circ} \mathrm{C} ; 50 \%\right. \\
\mathrm{RH})\end{array}$ & 86 \\
\hline $\begin{array}{l}\text { SPEEK } \\
\text { and } \\
\text { PES }\end{array}$ & $\begin{array}{l}30 \% \mathrm{w} / \mathrm{v} \text {. of } \\
\text { SPEEK in } \\
\text { DMAc }\end{array}$ & - & $\begin{array}{c}\text { Co-electrospun } \\
\text { sandwiched structure } \\
\text { composed of SPEEK } \\
\text { nanofibres as top and } \\
\text { bottom layers and PES } \\
\text { nanofibres in the centre; } \\
\text { Densification, LbL } \\
\end{array}$ & $\begin{array}{c}61\left(80{ }^{\circ} \mathrm{C} ; 100 \%\right. \\
\mathrm{RH})\end{array}$ & 114 \\
\hline
\end{tabular}




\begin{tabular}{|c|c|c|c|c|c|}
\hline & $\begin{array}{c}20 \% \text { w/v of PES } \\
\text { in DMAc }\end{array}$ & & $\begin{array}{c}\text { assembly of PDDA and } \\
\text { PSSA multilayers on } \\
\text { SPEEK nanofibre- } \\
\text { surface }\end{array}$ & & \\
\hline SPI & $11 \mathrm{wt} \%$ in DMF & $\begin{array}{c}\text { Sulfonated } \\
\text { Polyimide } \\
\text { copolymer (SCPI) } \\
\end{array}$ & $\begin{array}{c}\text { Uniaxially aligned SPI } \\
\text { nanofibres impregnated } \\
\text { with SCPI }\end{array}$ & NA & 59 \\
\hline PS & $\begin{array}{c}\text { 20-30 wt\% in } \\
\text { THF:DMF (1:4 } \\
\text { w/w) }\end{array}$ & Nafion ${ }^{\circledR}$ & $\begin{array}{c}\text { Sulfonation of } \\
\text { electrospun PS } \\
\text { nanofibre mat using } 10 \\
\mathrm{M} \mathrm{H}_{2} \mathrm{SO}_{4} \text { at } 100{ }^{\circ} \mathrm{C} \\
\text { followed by } \\
\text { impregnation with } \\
\text { Nafion }{ }^{\circledR} \\
\end{array}$ & $\begin{array}{c}180\left(80{ }^{\circ} \mathrm{C} ; 100\right. \\
\% \mathrm{RH})\end{array}$ & 117 \\
\hline $\begin{array}{c}\text { SPS and PEO } \\
\text { blend }(70 / 30 \mathrm{w} / \mathrm{w})\end{array}$ & - & $\begin{array}{c}\text { Vinyl-terminated } \\
\text { Poly } \\
\text { (dimethylsiloxane) } \\
\text { (PDMS) }\end{array}$ & $\begin{array}{l}\text { Cross-linking of SPS- } \\
\text { PEO nanofibre mat with } \\
\text { PDMS matrix }\end{array}$ & $\begin{array}{c}100\left(25^{\circ} \mathrm{C} ; 98 \%\right. \\
\mathrm{RH})\end{array}$ & 120 \\
\hline $\begin{array}{c}\text { SPEEK } \\
\text { and Silica }\left(\mathrm{SiO}_{2}\right) \\
\text { blend }(60 / 40 \mathrm{w} / \mathrm{w})\end{array}$ & $20 \mathrm{wt} \%$ in DMF & Nafion ${ }^{\circledR}$ & $\begin{array}{c}\text { SPEEK/ } \mathrm{SiO}_{2} \text { composite } \\
\text { nanofibre mat } \\
\text { impregnated with } \\
\text { Nafion }{ }^{\circledR} ; \text { Densified }\end{array}$ & $\begin{array}{c}77\left(90^{\circ} \mathrm{C} ; 100 \%\right. \\
\mathrm{RH})\end{array}$ & 115 \\
\hline SPAES & $\begin{array}{l}20 \mathrm{wt} \% \text { in } \\
\text { DMAc }\end{array}$ & Silicate & $\begin{array}{l}\text { In-situ sol gel synthesis } \\
\text { of the silicate inside the } \\
\text { pores of electrospun } \\
\text { SPAES mat }\end{array}$ & $\begin{array}{c}60\left(30{ }^{\circ} \mathrm{C} ; 100 \%\right. \\
\mathrm{RH})\end{array}$ & 112 \\
\hline
\end{tabular}

\section{Acknowledgement}

Funding from the European Research Council under the European Union's Seventh Framework Programme (FP/2007-2013) / ERC Grant Agreement n. 306682 is acknowledged.

\section{Abbreviations}

Proton Exchange Membrane Fuel Cells (PEMFC)

Direct Methanol Fuel Cell (DMFC)

Membrane Electrode Assembly (MEA)

Proton Exchange Membrane (PEM)

Alkaline Exchange Membranes (AEM)

3-dimensional (3D) 
Layer by layer (LbL)

Scanning Electron Microscopy (SEM)

Poly tetrafluoroethylene (PTFE)

Poly vinylidene fluoride (PVDF)

Polyvinyl alcohol (PVA)

Polystyrene (PS)

Poly ethylene oxide (PEO)

Polyimide (PI)

Polyphenylsulfone (PPSU)

Polybenzimidazole (PBI)

Perfluorosulfonic acid (PFSA)

Poly(acrylic acid) (PAA)

Poly(N-vinylpyrrolidone) (PVP)

Poly(styrenesulfonic acid) (PSSA)

Poly(ethersulfone) (PES)

Polyacrylonitrile (PAN)

Poly(diallyldimethyl ammonium chloride) (PDDA)

Poly-(trimethyl hexamethylene terephthalamide) (PTHTP)

Poly(phenyleneoxide) (PPO)

Poly(amide-co-imide)-poly(trimellitic anhydride chloride-co-4,4'-methylenedianiline) (PAIPTM) 
Poly(diallyl dimethyl ammonium chloride) (PDAC)

Sulfonated Polyimide copolymer (SCPI)

Sulfonated Poly (Arylene ether sulfone) (SPAES)

Sulfonated Poly (ether sulfone) (SPES)

Sulfonated polyhedral oligomeric silsesquioxane (sPOSS)

Sulfonated Poly (ether ether ketone) (SPEEK)

Sulfonated Polyimide (SPI)

Sulfonated Polystyrene (SPS)

Norland Optical Adhesive (NOA 63)

Cross-linked poly(2-acrylamido-2-meathylpropane-sulfonic acid) (C-PAMPS)

Chloromethylated polysulfone (CMPSF)

Bromomethylated Polyphenylene oxide (BPPO)

Ion Exchange Capacity (IEC)

Weight percent (wt\%)

Volume percent (vol\%)

Relative Humidity (RH)

Room Temperature (RT)

Dimethylformamide (DMF)

Dimethylacetamide (DMAc)

Dimethylsulfoxide (DMSO)

Tetrahydrofuran (THF) 
Isopropyl alcohol (IPA)

N-Methly-2-pyrrolidone (NMP)

3-glycidyloxypropyl trimethoxysilane (GPTMS)

Orthophosphoric acid $\left(\mathrm{H}_{3} \mathrm{PO}_{4}\right)$

3-trihydroxysilyl-1-propanesulfonic acid (THPSA)

Cesium dihydrogen phosphate (CDP)

Sulfated zirconia $\left(\mathrm{S}-\mathrm{ZrO}_{2}\right)$

Sulfonic acid (SA)

Phosphoric acid (PA)

Silica $\left(\mathrm{SiO}_{2}\right)$

Cetyltrimethylammonium bromide (CTAB)

Benzoyl peroxide (BPO)

Divinylbenzene (DVB)

Glutaraldehyde (GA)

Not available (NA)

Solution (Sol.)

Proton Conductivity $(\sigma)$

Power Density (P)

Ultra-violet rays (UV)

Equivalent weight (EW)

Deionised (DI) 
Acid Doping Level (ADL)

\section{References}

[1] Y. Wang, K.S. Chen, J. Mishler, S.C. Cho, X.C. Adroher, Appl. Energy 88 (2011) 9811007.

[2] R.E. Clarke, S. Giddey, S.P.S. Badwal, Int. J. Hydrogen Energy 35 (2010) 928-935.

[3] Q. Li, R. He, J.O. Jensen, N.J. Bjerrum, Chem. Mater. 15 (2003) 4896-4915.

[4] F.A. De Bruijn, V.A.T. Dam, G.J.M. Janssen, Fuel Cells 8 (2008) 3-22.

[5] R. Borup, J. Meyers, B. Pivovar, Y.S. Kim, R. Mukundan, N. Garland, D. Myers, M. Wilson, F. Garzon, D. Wood, P. Zelenay, K. More, K. Stroh, T. Zawodzinski, X.J. Boncella, J.E. Mcgrath, O.M. Inaba, K. Miyatake, M. Hori, K. Ota, Z. Ogumi, S. Miyata, A. Nishikata, Z. Siroma, Y. Uchimoto, K. Yasuda, K. Kimijima, N. Iwashita, Chem. Rev. 107 (2007) 3904-3951.

[6] V. Neburchilov, J. Martin, H. Wang, J. Zhang, J. Power Sources 169 (2007) 221-238.

[7] D.J. Jones, J. Rozière, J. Memb. Sci. 185 (2001) 41-58.

[8] J. Rozière, D.J. Jones, Annu. Rev. Mater. Res. 33 (2003) 503-555.

[9] D.J. Jones, in: Polymer Electrolyte Membrane and Direct Methanol Fuel Cell Technology, (2012) 27-55.

[10] J.R. Varcoe, P. Atanassov, D.R. Dekel, A.M. Herring, M.A. Hickner, P.A. Kohl, A.R. Kucernak, W.E. Mustain, K. Nijmeijer, K. Scott, T. Xu, L. Zhuang, Energy Environ. Sci. 7 (2014) 3135-3191.

[11] S.J. Peighambardoust, S. Rowshanzamir, M. Amjadi, Int J Hydrogen Energy, 35 (2010) 9349-9384.

[12] B. Smitha, S. Sridhar, A.A. Khan, J. Memb. Sci. 259 (2005) 10-26.

[13] M.A. Hickner, H. Ghassemi, Y.S. Kim, B.R. Einsla, J.E. McGrath, Chem. Rev. 104 (2004) 4587-4611.

[14] R. Wycisk, P. Pintauro, J. Park, Curr. Opin. Chem. Eng. 4 (2014) 71-78.

[15] H.S. Thiam, W.R.W. Daud, S.K. Kamarudin, A.B. Mohammad, A.A.H. Kadhum, K.S. Loh, E.H. Majlan, Int. J. Hydrogen Energy 36 (2011) 3187-3205.

[16] J.C. Perrin, S. Lyonnard, F. Volino, J. Phys. Chem. C 111 (2007) 3393-3404.

[17] K.A. Mauritz, R.B. Moore, Chem. Rev. 104 (2004) 4535-4585.

[18] K.D. Kreuer, G. Portale, Adv. Funct. Mater. 23 (2013) 5390-5397.

[19] R. Sood, C. Iojoiu, E. Espuche, F. Gouanve, G. Gebel, H. Mendil-jakani, S. Lyonnard, J. Jestin, J. Phys. Chem. C 118 (2014) 14157-14168.

[20] S. Subianto, M. Pica, M. Casciola, P. Cojocaru, L. Merlo, G. Hards, D.J. Jones, J. Power Sources 233 (2013) 216-230. 
[21] A. Ghielmi, P. Vaccarono, C. Troglia, V. Arcella, J. Power Sources 145 (2005) 108-115.

[22] D.J. Jones, Aldrich Mater. Sci. 10 (2015) 88-99.

[23] O. Savadogo, J. Power Sources 127 (2004) 135-161.

[24] G.G. Scherer, ed., Fuel Cells I, Springer-Verlag, Berlin Heidelberg, 2008.

[25] P. Jannasch, Curr. Opin. Colloid Interface Sci. (2003) 96-102.

[26] T. Higashihara, K. Matsumoto, M. Ueda, Polymer 50 (2009) 5341-5357.

[27] G. Alberti, M. Casciola, Annu. Rev. Mater. Res. 33 (2003) 129-154.

[28] F. NG, J. Peron, D.J. Jones, J. Roziere, J. Polym. Sci. PART A Polym. Chem. 49 (2011) 2107-2117.

[29] J. Peron, E. Ruiz, D.J. Jones, J. Rozière, J. Memb. Sci. 314 (2008) 247-256.

[30] F. Ng, D.J. Jones, J. Roziere, B. Bauer, M. Schuster, M. Jeske, J. Memb. Sci. 362 (2010) 184-191.

[31] T.J. Peckham, S. Holdcroft, Adv. Mater. 22 (2010) 4667-4690.

[32] C.H. Park, C.H. Lee, M.D. Guiver, Y.M. Lee, Prog. Polym. Sci. 36 (2011) 1443-1498.

[33] D.S. Kim, A. Labouriau, M.D. Guiver, Y.S. Kim, Chem. Mater. 23 (2011) 3795-3797.

[34] B. Bae, T. Yoda, K. Miyatake, H. Uchida, M. Watanabe, Angew. Chemie 49 (2010) $317-$ 320.

[35] M. Tanaka, M. Koike, K. Miyatake, M. Watanabe, Macromolecules 43 (2010) 26572659.

[36] J.T. Wang, R.F. Savinell, J. Wainright, M. Litt, H. Yu, Electrochim. Acta 41 (1996) 193197.

[37] K.D. Kreuer, A. Fuchs, M. Ise, M. Spaeth, J. Maier, Electrochim. Acta 43 (1998) 12811288.

[38] R. Sood, C. Iojoiu, E. Espuche, F. Gouanve, G. Gebel, H. Mendil-jakani, S. Lyonnard, J. Jestin, J. Phys. Chem. C 116 (2012) 24413-24423.

[39] R. Sood, C. Iojoiu, E. Espuche, F. Gouanvé, H. Mendil-Jakani, S. Lyonnard, J. Memb. Sci. 495 (2015) 445-456.

[40] K.M.Nouel, P.S. Fedkiw, Electrochim. Acta 43 (1998) 16-17.

[41] F. Liu, B. Yi, D. Xing, J. Yu, H. Zhang, J. Memb. Sci. 212 (2003) 213-223.

[42] B. Bahar, A.R. Hobson, J.A. Kolde, D. Zuckerbrod, Ultra-Thin Integral Composite Membrane, US5547551 A, 1996.

[43] H.L. Lin, T.L. Yu, L.N. Huang, L.C. Chen, K.S. Shen, G.B. Jung, J. Power Sources 150 (2005) 11-19.

[44] S. Banerjee, D.N. Prugh, S. Frisk, ECS Trans. 50 (2012) 887-895.

[45] D. Jones, J. Rozière, Adv . Polym. Sci. 215 (2008) 219-264.

[46] S. Sambandam, V. Ramani, J. Power Sources 170 (2007) 259-267.

[47] K.T. Adjemian, R. Dominey, L. Krishnan, H. Ota, P. Majsztrik, T. Zhang, J. Mann, B. Kirby, L. Gatto, M. Velo-Simpson, J. Leahy, S. Srimvasan, J.B. Benziger, A.B. Bocarsly, Chem. Mater. 18 (2006) 2238-2248.

[48] Z. Chen, B. Holmberg, W. Li, X. Wang, W. Deng, R. Munoz, Y. Yan, Chem. Mater. 18 
(2006) 5669-5675.

[49] G. Alberti, M. Casciola, D. Capitani, A. Donnadio, R. Narducci, M. Pica, M. Sganappa, Electrochim. Acta 52 (2007) 8125-8132.

[50] V. di Noto, S. Lavina, E.Negro, M. Vittadello, F. Conti, M. Piga, G. Pace, J. Power Sources 187 (2009) 57-66.

[51] D. Li, Y. Xia, Adv. Mater. 16 (2004) 1151-1170.

[52] Z.M. Huang, Y.Z. Zhang, M. Kotaki, S. Ramakrishna, Compos. Sci. Technol. 63 (2003) 2223-2253.

[53] S. Cavaliere, S. Subianto, I. Savych, D.J. Jones, J. Rozière, Energy Environ. Sci. 4 (2011) 4761-4785.

[54] V. Thavasi, G. Singh, S. Ramakrishna, Energy Environ. Sci. 1 (2008) 205-221.

[55] S. Peng, L. Li, J.L. Kong Yoong, L. Tian, M. Srinivasan, S. Adams, S. Ramakrishna, Nano Energy (2016).

[56] S. Subianto, S. Giancola, G. Ercolano, Y. Nabil, D. Jones, J. Rozière, in: S. Cavaliere (Ed.), Electrospinning for Advanced Energy and Environmental Applications (2015) 2960.

[57] M. V. Kakade, S. Givens, K. Gardner, K.H. Lee, D.B. Chase, J.F. Rabolt, J. Am. Chem. Soc. 129 (2007) 2777-2782.

[58] S.F. Fennessey, R.J. Farris, Polymer 45 (2004) 4217-4225.

[59] T. Tamura, H. Kawakami, Nano Lett. 10 (2010) 1324-1328.

[60] C. Pan, H. Wu, C. Wang, B. Wang, L. Zhang, Z. Cheng, P. Hu, W. Pan, Z. Zhou, X. Yang, J. Zhu, Adv. Mater. 20 (2008) 1644-1648.

[61] S. Cavaliere, ed., Electrospinning for Advanced Energy and Environmental Applications, CRC Press, 2015.

[62] S.K. Palaniswamy, J. Sundaramurthy, S. Sundarrajan, V.J. Babu, G. Singh, S.I. Allakhverdiev, S. Ramakrishna, Energy Environ. Sci. 7 (2014) 3192-3222.

[63] W.G. Jang, J. Hou, H.S. Byun, Desalin. Water Treat. 34 (2011) 315-320.

[64] S.W. Choi, Y.Z. Fu, Y.R. Ahn, S.M. Jo, A. Manthiram, J. Power Sources 180 (2008) $167-171$

[65] S. Mollá, V. Compañ, J. Memb. Sci. 372 (2011) 191-200.

[66] J.M. Lim, J.H. Won, H.J. Lee, Y.T. Hong, M.S. Lee, C.H. Ko, S.Y. Lee, J. Mater. Chem. 22 (2012) 18550-18557.

[67] H.J. Lee, J.H. Kim, J.H. Won, J.M. Lim, Y.T. Hong, S.Y. Lee, ACS Appl. Mater. Interfaces 5 (2013) 5034-5043.

[68] H.Y. Li, Y.L. Liu, J. Mater. Chem. A 2 (2014) 3783-3793.

[69] S. Shahgaldi, M. Ghasemi, W.R. Wan Daud, Z. Yaakob, M. Sedighi, J. Alam, A.F. Ismail, Fuel Process. Technol. 124 (2014) 290-295.

[70] H.Y. Li, Y.Y. Lee, J.Y. Lai, Y.L. Liu, J. Memb. Sci. 466 (2014) 238-245.

[71] M.M. Mannarino, D.S. Liu, P.T. Hammond, G.C. Rutledge, ACS Appl. Mater. Interfaces 5 (2013) 8155-8164.

[72] D.M. Yu, S. Yoon, T.H. Kim, J.Y. Lee, J. Lee, Y.T. Hong, J. Memb. Sci. 446 (2013) 212-219. 
[73] C. Nah, K.U. Jeong, Y.S. Lee, S.H. Lee, M.M.A. Kader, H.K. Lee, J.H. Ahn, Polym. Int. 62 (2013) 375-381.

[74] D.M. Yu, S. Yoon, T.H. Kim, J.Y. Lee, J. Lee, Y.T. Hong, Macromol. Res. 22 (2014) 79-84.

[75] J. Jin, R. Hao, X. He, G. Li, Int. J. Hydrogen Energy 40 (2015) 14421-14427.

[76] K.Y. Cho, H.Y. Jung, N.S. Choi, S.J. Sung, J.K. Park, J.H. Choi, Y.E. Sung, Solid State Ionics 176 (2005) 3027-3030.

[77] H.J. Kim, H.J. Kim, Y.G. Shul, H.S. Han, J. Power Sources 135 (2004) 66-71.

[78] M.M. Nasef, N.A. Zubir, A.F. Ismail, K.Z.M. Dahlan, H. Saidi, M. Khayet, J. Power Sources 156 (2006) 200-210.

[79] K.Y. Cho, H.Y. Jung, K. a. Sung, W.K. Kim, S.J. Sung, J.K. Park, J.H. Choi, Y.E. Sung, J. Power Sources 159 (2006) 524-528.

[80] M.K. Song, Y.T. Kim, J.M. Fenton, H. Russell Kunz, H.W. Rhee, J. Power Sources 117 (2003) 14-21.

[81] S. Giancola, A. Reyes Carmona, S. Cavaliere, M. Dupont, J. Rozière, D. Jones, Submitted (n.d.).

[82] Y. He, H. Zhang, Y. Li, J. Wang, L. Ma, W. Zhang, J. Liu, J. Mater. Chem. A 3 (2015) 21832-21841.

[83] D. Jones, J. Rozière, S. Subianto, S. Cavaliere, Reinforced Ionomer Membranes, Fabrication and Application in Energy Conversion Devices, 1413794.7, 2014.

[84] J.B. Ballengee, P.N. Pintauro, Macromolecules 44 (2011) 7307-7314.

[85] J.B. Ballengee, G.M. Haugen, S.J. Hamrock, P.N. Pintauro, J. Electrochem. Soc. 160 (2013) F429-F435.

[86] J.B. Ballengee, P.N. Pintauro, J. Memb. Sci. 442 (2013) 187-195.

[87] E.H. Sanders, K.A. McGrady, G.E. Wnek, C.A. Edmondson, J.M. Mueller, J.J. Fontanella, S. Suarez, S.G. Greenbaum, J. Power Sources 129 (2004) 55-61.

[88] S. Shenoy, W. Bates, H. Frisch, G. Wnek, Polymer 46 (2005) 3372-3384.

[89] S. Jiang, K.Q.Q. Xia, G.G. Xu, Macromolecules 34 (2001) 7783-7788.

[90] A. Laforgue, L. Robitaille, A. Mokrini, A. Ajji, Macromol. Mater. Eng. 292 (2007) 1229-1236.

[91] J. Choi, K.M. Lee, R. Wycisk, P.N. Pintauro, P.T. Mather, J. Mater. Chem. 20 (2010) 6282-6290.

[92] T. Song, Z. Chen, H. He, Y. Liu, Y. Liu, S. Ramakrishna, J. Appl. Polym. Sci. 132 (2015) 41755.

[93] J. Zhao, W.Z. Yuan, A. Xu, F. Ai, Y. Lu, Y. Zhang, React. Funct. Polym. 71 (2011) 11021109.

[94] H. Chen, J.D. Snyder, Y.A. Elabd, Macromolecules 41 (2008) 128-135.

[95] K.M. Lee, J. Choi, R. Wycisk, P.N. Pintauro, P. Mather, ECS Trans. 25 (2009) 14511458.

[96] J.B. Ballengee, P.N. Pintauro, J. Electrochem. Soc. 158 (2011) B568-B572.

[97] B. Dong, L. Gwee, D. Salas-De La Cruz, K.I. Winey, Y.A. Elabd, Nano Lett. 10 (2010) 3785-3790. 
[98] S. Subianto, S. Cavaliere, D.J. Jones, J. Rozière, J. Polym. Sci. Part A Polym. Chem. 51 (2013) 118-128.

[99] S. Subianto, S. Cavaliere, D.J. Jones, J. Rozière, ECS Trans. 41 (2011) 1517-1520.

[100] C. Subramanian, R.A. Weiss, M.T. Shaw, Polymer 51 (2010) 1983-1989.

[101] R. Takemori, G. Ito, M. Tanaka, H. Kawakami, RSC Adv. 4 (2014) 20005-20009

[102] X. Li, X. Hao, D. Xu, G. Zhang, S. Zhong, H. Na, D. Wang, J. Memb. Sci. 281 (2006) $1-6$.

[103] S. Roddecha, Z. Dong, Y. Wu, M. Anthamatten, J. Memb. Sci. 389 (2012) 478-485.

[104] J. Choi, K.M. Lee, R. Wycisk, P.N. Pintauro, P.T. Mather, Macromolecules 41 (2008) 4569-4572.

[105] P.P. Lu, Z.L. Xu, H. Yang, Y.M. Wei, H.T. Xu, J. Polym. Res. 19 (2012) 9854-9864.

[106] B. Wu, J. Pan, L. Ge, L. Wu, H. Wang, T. Xu, Sci. Rep. 4 (2014) 1-7.

[107] R. Boonpoo-nga, M. Sriring, P. Nasomjai, S. Martwiset, ScienceAsia 40 (2014) 232237.

[108] S. Zhang, G. He, X. Gong, X. Zhu, X. Wu, X. Sun, X. Zhao, H. Li, J. Memb. Sci. 493 (2015) 58-65.

[109] J. Choi, R. Wycisk, W. Zhang, P.N. Pintauro, K.M. Lee, P.T. Mather, ChemSusChem 3 (2010) 1245-1248.

[110] J. Choi, K.M. Lee, R. Wycisk, P.N. Pintauro, P.T. Mather, J. Electrochem. Soc. 157 (2010) B914-B919.

[111] L. Wang, J. Zhu, J. Zheng, S. Zhang, L. Dou, RSC Adv. 4 (2014) 25195-25200.

[112] J.H. Won, H.J. Lee, J.M. Lim, J.H. Kim, Y.T. Hong, S.Y. Lee, J. Memb. Sci. 450 (2014) $235-241$.

[113] J. Choi, C. Lee, S.C. Hawkins, C.P. Huynh, J. Park, Y. Jeon, Y.B. Truong, I.L. Kyratzis, Y.G. Shul, R.A. Caruso, RSC Adv. 4 (2014) 32787-32790.

[114] W. Liu, S. Wang, M. Xiao, D. Han, Y. Meng, Chem. Commun. 48 (2012) 3415.

[115] C. Lee, S.M. Jo, J. Choi, K.Y. Baek, Y.B. Truong, I.L. Kyratzis, Y.G. Shul, J. Mater. Sci. 48 (2013) 3665-3671.

[116] Y. Yao, B. Guo, L. Ji, K.H. Jung, Z. Lin, M. Alcoutlabi, H. Hamouda, X. Zhang, Electrochem. Commun. 13 (2011) 1005-1008.

[117] Y. Yao, L. Ji, Z. Lin, Y. Li, M. Alcoutlabi, H. Hamouda, X. Zhang, ACS Appl. Mater. Interfaces 3 (2011) 3732-3737.

[118] M.M. Hasani-Sadrabadi, I. Shabani, M. Soleimani, H. Moaddel, J. Power Sources 196 (2011) 4599-4603.

[119] I. Shabani, M.M. Hasani-Sadrabadi, V. Haddadi-Asl, M. Soleimani, J. Memb. Sci. 368 (2011) 233-240.

[120] C. Subramanian, R.A. Weiss, M.T. Shaw, Ind. Eng. Chem. Res. 52 (2013) 15088-15093.

[121] S. Mollá, V. Compañ, J. Memb. Sci. 492 (2015) 123-136.

[122] J.B. Ballengee, P.N. Pintauro, ECS Trans. Electrochem. Soc. 33 (2010) 647-658.

[123] M. Oroujzadeh, S. Mehdipour-Ataei, M. Esfandeh, Chem. Eng. J. 269 (2015) 212-220.

[124] M.M. Hasani-Sadrabadi, E. Dashtimoghadam, F.S. Majedi, J.J. VanDersarl, A. Bertsch, 
P. Renaud, K.I. Jacob, Nano Energy (2016) 1-8.

[125] J.A. Kerres, J. Memb. Sci. 185 (2001) 3-27.

[126] H.S. Thiam, W.R.W. Daud, S.K. Kamarudin, A.B. Mohamad, A.A.H. Kadhum, K.S. Loh, E.H. Majlan, Int. J. Hydrogen Energy 38 (2013) 9474-9483.

[127] Z. Shami, N. Sharifi-Sanjani, B. Khanyghma, S. Farjpour, A. Fotouhi, RSC Adv. 4 (2014) 40892-40897.

[1287]S. Subianto, A. Donnadio, S. Cavaliere, M. Pica, M. Casciola, D.J. Jones, J. Rozière, J. Mater. Chem. A 2 (2014) 13359-13365.

[129] K. Ketpang, K. Lee, S. Shanmugam, Appl. Mater. Interfaces 6 (2014) 16734-16744.

[130] T.E. Kim, S.M. Juon, J.H. Park, Y.G. Shul, K.Y. Cho, Int. J. Hydrogen Energy 39 (2014) 16474-16485.

[131] K. Ketpang, S. Shanmugam, C. Suwanboon, N. Chanunpanich, D. Lee, J. Memb. Sci. 493 (2015) 285-298.

[132] L. Brandão, J. Rodrigues, L.M. Madeira, A. Mendes, Int. J. Hydrogen Energy 35 (2010) 11561-11567.

[133] Y.M. Kim, K.W. Park, J.H. Choi, I.S. Park, Y.E. Sung, Electrochem. Commun. 5 (2003) 571-574.

[134] A. Goñi-Urtiaga, K. Scott, S. Cavaliere, D.J. Jones, J. Rozière, J. Mater. Chem. A 1 (2013) 10875-10880.

[135] C. Laberty-Robert, K. Vallé, F. Pereira, C. Sanchez, Chem. Soc. Rev. 40 (2011) 961 1005.

[136] V. Maneeratana, J.D.Bass, T. Azais, A. Patissier, K. Vallé, M. Marechal, G. Gebel, C. Laberty-Robert, C. Sanchez, Adv. Funct. Mater. 23 (2013) 2872-2880.

[137] L.D. Santos, M. Marechal, A. Guillermo, S. Lyonnard, S. Moldovan, O. Ersen, O. Sel, H. Perrot, C. Laberty-Robert, Adv. Funct. Mater. 26 (2016) 594-604.

[138] S.H. Yun, J.J. Woo, S.J. Seo, L. Wu, D. Wu, T. Xu, S.H. Moon, J. Memb. Sci. 367 (2011) 296-305.

[139] H.Y. Li, Y.L. Liu, J. Mater. Chem. A 1 (2013) 1171-1178.

[140] S. Mollá, V. Compañ, E. Gimenez, A. Blazquez, I. Urdanpilleta, Int. J. Hydrogen Energy 36 (2011) 9886-9895.

[141] H.L. Lin, S.H. Wang, C.K. Chiu, T.L. Yu, L.C. Chen, C.C. Huang, T.H. Cheng, J.M. Lin, J. Memb. Sci. 365 (2010) 114-122.

[142] S. Mollá, V. Compañ, J. Power Sources 196 (2011) 2699-2708.

[143] H.L. Lin, S.H. Wang, J. Memb. Sci. 452 (2014) 253-262.

[144] S.D. Mikhailenko, G.P. Robertson, M.D. Guiver, S. Kaliaguine, J. Memb. Sci. 285 (2006) 306-316.

[145] A.M. Park, P.N. Pintauro, Electrochem. Solid-State Lett. 15 (2012) B27-B30.

[146] A.M. Park, F.E. Turley, R.J. Wycisk, P.N. Pintauro, Macromolecules 47 (2014) 227235.

[147] A.M. Park, R.J. Wycisk, X. Ren, F.E. Turley, P.N. Pintauro, J. Mater. Chem. A 432 (2016) 132-141.

[148] E. Quartarone, P. Mustarelli, Energy Environ. Sci. 5 (2011) 6436-6444. 
[149] S. Subianto, Polym. Int. 63 (2014) 1134-1144.

[150] A. Kreisz, PhD Thesis, University of Montpellier, 2016.

[151] Y. Nedellec, N. Donzel, A. Kreisz, D. Jones, J. Rozière, in:, ECS Meet. Abstr. MA201503 638, 2015. 